\title{
As características pós-modernas na obra Rimsky de Gilberto Mendes
}

\author{
Vera Lúcia Rocha Pedron Peres (USP, São Paulo, SP) \\ verarochape@hotmail.com
}

Resumo: 0 pós-modernismo na música ainda busca critérios que permitam sua compreensão, entre eles traços como fragmentação, descontinuidade, citação, justaposição de estilos e pluralismo. 0 presente estudo visa demonstrar as características pós-modernas na obra Rimsky de Gilberto Mendes por meio da análise de suas referências existentes, tendo em vista os procedimentos que norteiam as composições e os pressupostos pós-modernos. Além da identificação dos elementos paradigmáticos, e para ir além de uma abordagem indutiva (limitante, porque sincrônica), busca-se a identificação da obra em relação ao modernismo (de crítica e de extensão), enfatizando suas diferenças constatadas na sintaxe, na epistemologia e na ideologia. São abordados os limites conceituais que se aproximam e se distanciam do modernismo buscando contribuir na reflexão da arte na atualidade.

Palavras-chave: Gilberto Mendes; Rimsky; quinteto; pós-modernismo; sintaxe musical; descontinuidade musical; pluralismo musical; fragmentação musical; citação musical.

\section{Postmodern characteristics in the work Rimsky by Brazilian composer Gilberto Mendes}

Abstract: Postmodernism in music still needs criteria to facilitate its understanding, such as traits like fragmentation, discontinuity, quotation, juxtaposition of styles and pluralism. This study aims at demonstrating the postmodern characteristics in the work Rimsky by Brazilian composer Gilberto Mendes by means of analysing its existing references and having in mind the procedures that organize postmodern assumptions and musical compositions. Besides the identification of paradigmatic elements, and in order to surpass a simply inductive approach (restrictive because of its synchronic nature), it tries to connect the work to modernism (in both criticism and extended fields), emphasizing its differences in syntax, epistemology and ideology. The conceptual limits that make it closer and apart from modernism are discussed as an attempt to contribute to the reflection about the art today.

Keywords: Gilberto Mendes; quintet; Rimsky; postmodernism; musical syntax; musical discontinuity; musical pluralism; musical fragmentation; musical quotation.

\section{Introdução}

Originalmente criado na década de 1930 por Federico de Onís1 a ideia de um estilo pós-moderno não tem atualmente nada da precisão que este Ihe atribuía. Em nossa contemporaneidade pós-moderno é uma palavra composta que incorre em equívocos. Aplicado em várias áreas diferentes, este termo ressurgiu nos anos 80 sem sua exata definição. 0 que é pós-moderno? Como defini-lo?

É importante retermos que o prefixo "pós" não significa apenas depois no tempo. "Pós" admite aspectos estéticos de ruptura e de extensão do modernismo. A discussão sobre a imprecisão da palavra pós-moderno como um termo composto cujo significado depende do significado variável que se adote em relação ao modernismo gerou controvérsias entre os teóricos. Das discussões travadas depreendeu-se a conclusão de que pós-moderno não é uma categoria que possa caracterizar nosso zeitgeist em todos os seus aspectos e com claros critérios definidos. 0 termo "pós-moderno" cujo "moderno" está implícito foi defendido a partir de vários posicionamentos sem nenhum consenso. "Pós-modernismo", portanto, deve ser considerado como uma extensão do modernismo, do contrário, toda a música não-moderna desde o fim do século XIX poderia ser classificada como pós-moderna. Em termos estéticos, se fragmentação, justaposição, citação, pluralismo, não são categorias estritamente pósmodernas onde devemos situar sua diferença? 
0 percurso adotado neste trabalho efetua a análise da obra Rimsky (2003) de Gilberto Mendes a partir da afirmação dos autores Boudewijn BUCKINX² e Rodolfo COELHO DE SOUZA ${ }^{3}$ que o apontam como um compositor pós-moderno para verificar as principais características que possam pontuar essa hipótese e que permitam exemplificar, esclarecer, corroborar uma apuração objetiva dessa tendência estética, como tentativa de detectar uma mudança estrutural.

\section{Apresentação da obra Rimsky de Gilberto Mendes}

A obra Rimsky (composta em 2003, na 3a. fase de Mendes) inicia-se com a introdução de uma série atípica (isto é, não dodecafônica ortodoxa) que cria uma circunspecção na escuta. De desenvoltura rizomática ${ }^{4}$, descontínua, implica na possibilidade de mudança que se transforma numa ordem diversa, delineiam-se fragmentos de citações, estilemas ${ }^{5}$ que se sucedem através de acordes/ obstáculos, sem conexões. Aludindo períodos e estilos diferentes e apesar da fragmentação e choques de significados, resulta num só fio condutor onde o clima imperante (salvo o trecho atonal, mais abstrato e mais denso) é de alegria (pertencentes ao repertório popular como: ritmos de dança, música de cinema, bossa-nova), ou seja, que promove o envolvimento direto do ouvinte através do reconhecimento de uso de referências que primam pela exclusão da intelectualidade e da seriedade.

Evidenciamos em sua fatura a preferência do autor pelo uso de acordes de 9a., que evocam o universo harmônico do impressionismo e do jazz.

A associação livre delineia-se incitando a imaginação e a memória, permitindo ao ouvinte a possibilidade de efetuar reconhecimentos. 0 fluir dos acontecimentos novos se sucede até decorrer um terço da obra quando passa a ser realimentado pelos fragmentos passados em sobreposição constituindo um ritornello sem final conclusivo. Apresenta diferentes andamentos relacionados em uma única estrutura. A notação é tradicional. 0 aspecto temporal é métrico, os parâmetros são tradicionais (melodia, uso da barra de compasso). 0 aspecto harmônico é ora tonal, ora atonal, ora modal, às vezes ambíguo (quando verificado na utilização da série e seus desdobramentos).

A formação instrumental é tradicional. Vale observar: nesta, como em outras obras, o autor não dá nomes tradicionais de formas às suas músicas, mas nome literário. No entanto, Rimsky é um quinteto para piano e cordas. Examinemos com exemplos musicais esses procedimentos que serão utilizados nas análises subsequentes.

\section{Listagem das referências existentes: ${ }^{6}$}

Os exemplos Ex.1 a Ex.16 trazem as referências em Rimsky de Gilberto Mendes discutidas nesse artigo.

Viol.I

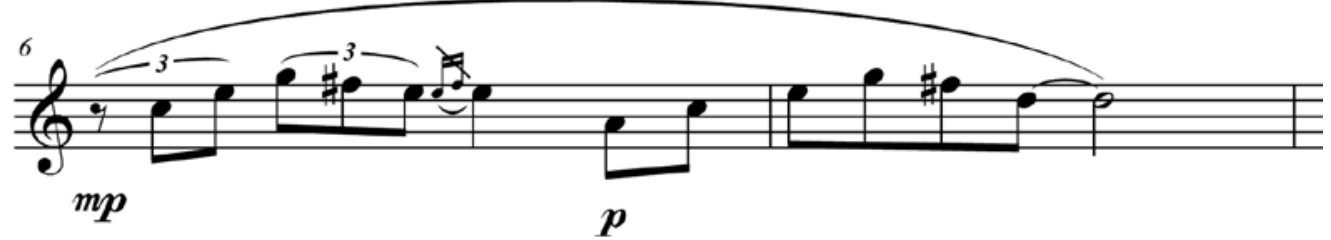

Ex.1 - Citação de Sheherazade (recitativo) em Rimsky de Gilberto Mendes (c.6-7)

Viol.I

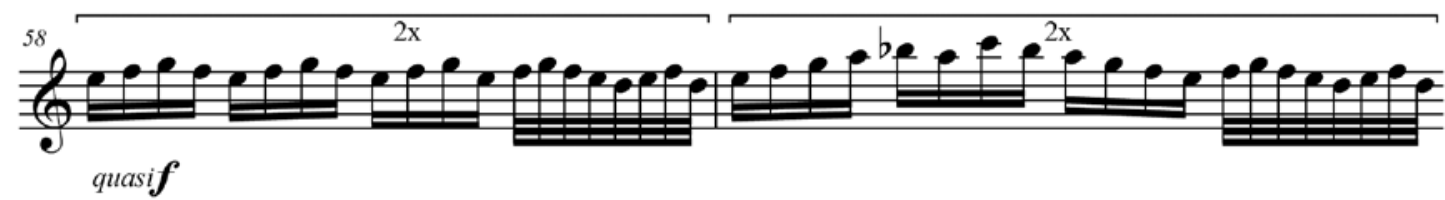

Ex.2 - Elementos inspirados em Sheherazade em Rimsky de Gilberto Mendes (c.58-59)

Viol.I

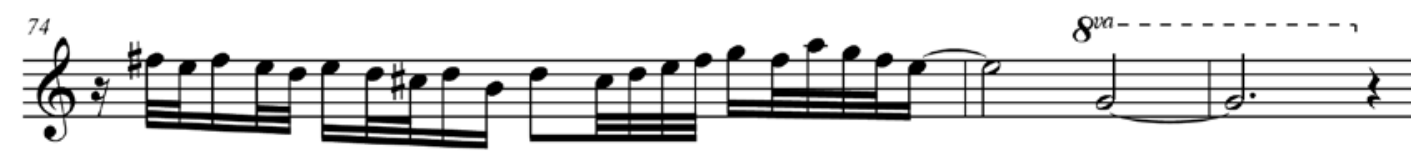

Ex.3 - Elementos de Sheherazade transformada em Rimsky de Gilberto Mendes (c.74-76) 
Viol.I

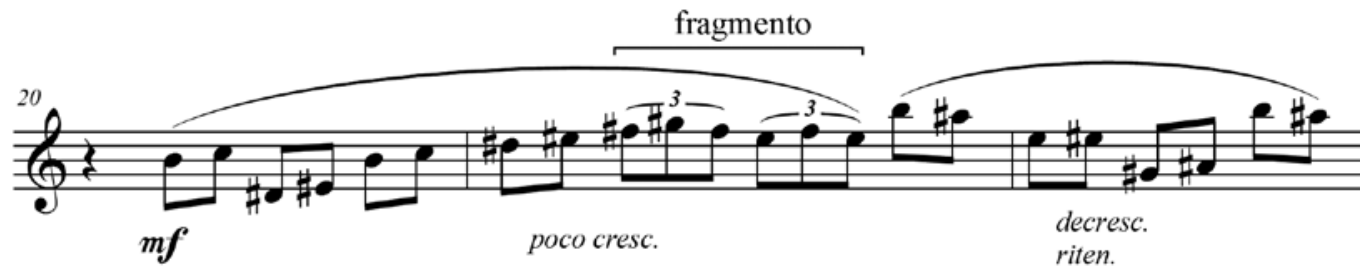

Ex.4 - Elementos livres com fragmentos de citação de Sheherazade em Rimsky de Gilberto Mendes (c.20-22)

fragmento

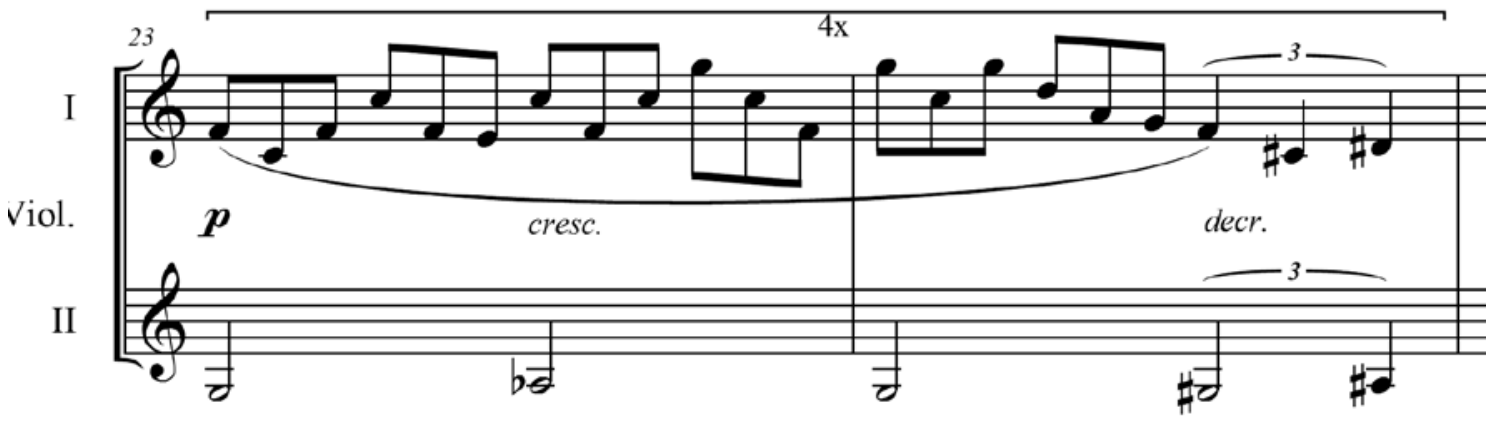

Ex.5 - Minimalismo em Rimsky de Gilberto Mendes (c.23-24)

Viol.I
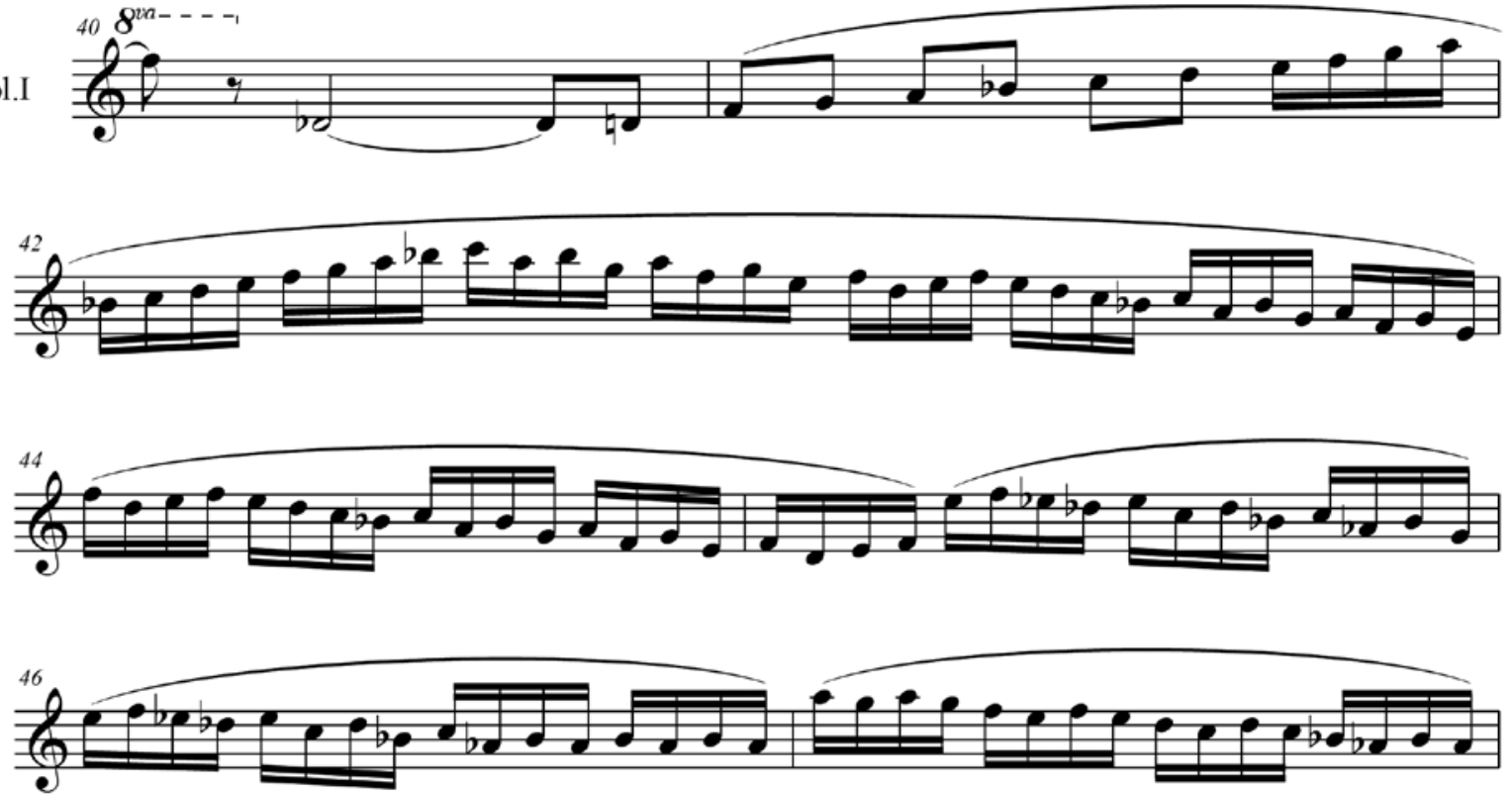

Ex.6 - Música para cinema em Rimsky de Gilberto Mendes (c.40-47) 
(etc.)

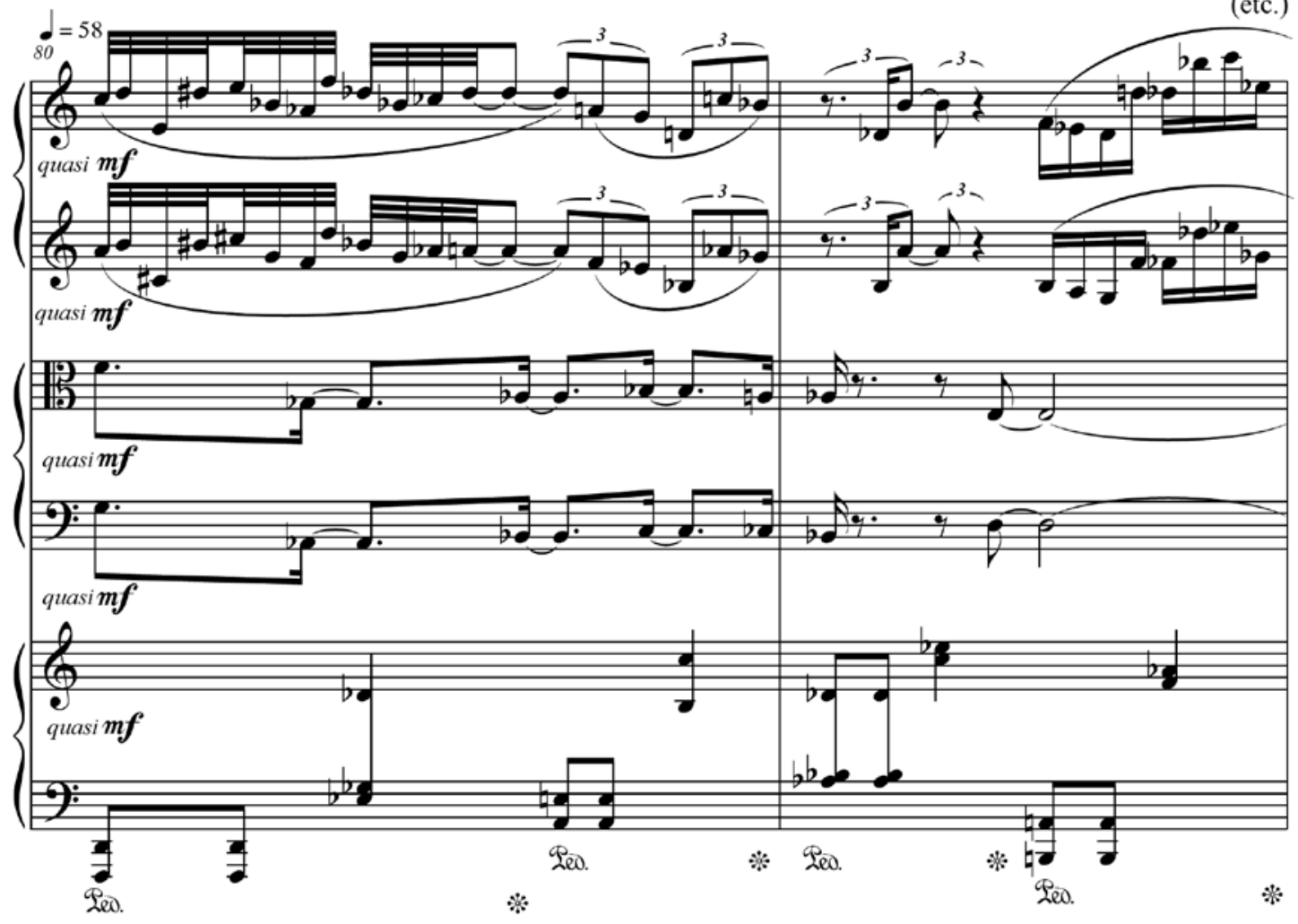

Ex.7 - Trecho atonal em Rimsky de Gilberto Mendes (c.80 - 94, p.18)

cadenza per piano solo
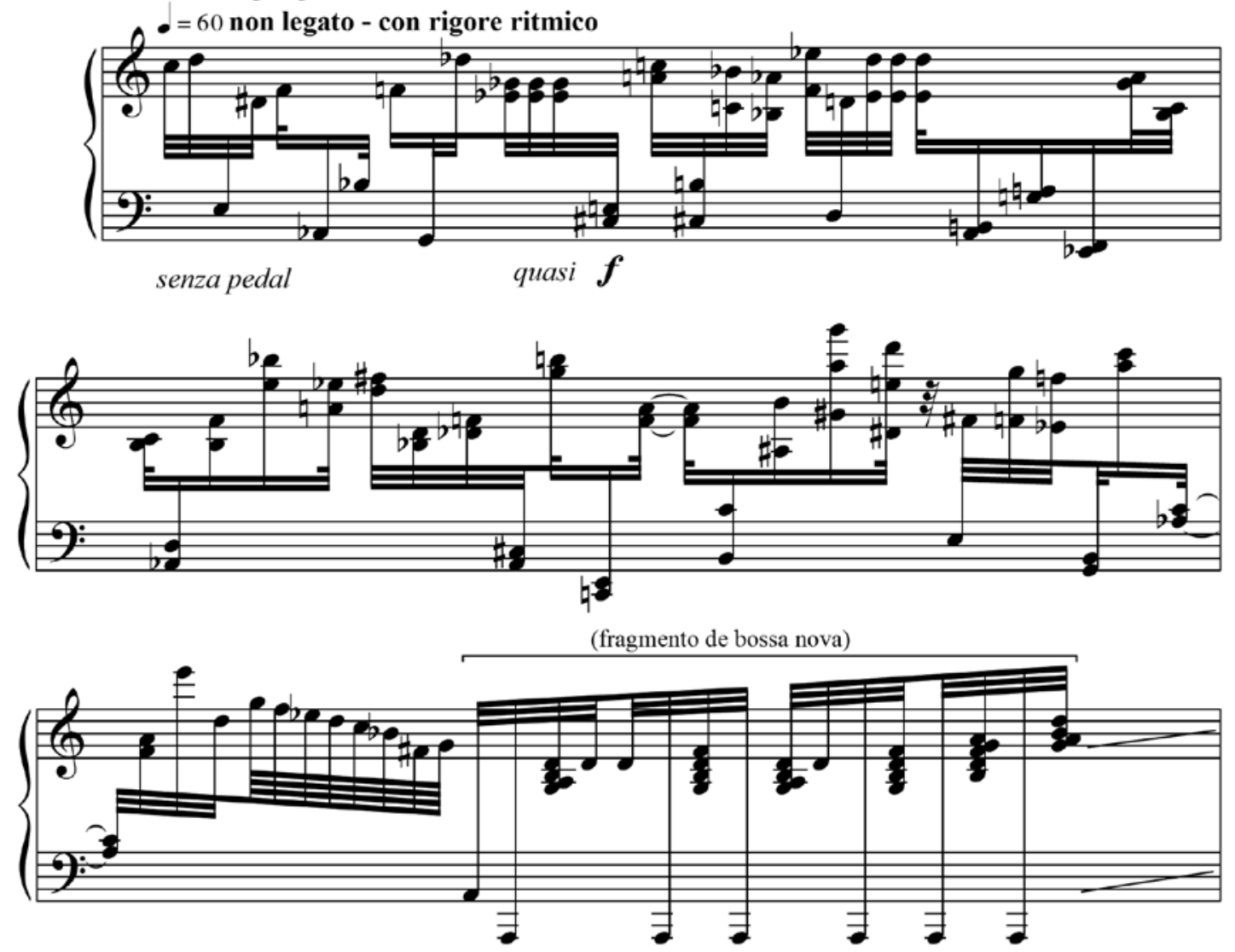

Ex.8 - Cadenza para piano em Rimsky de Gilberto Mendes (c.95 - 102) 

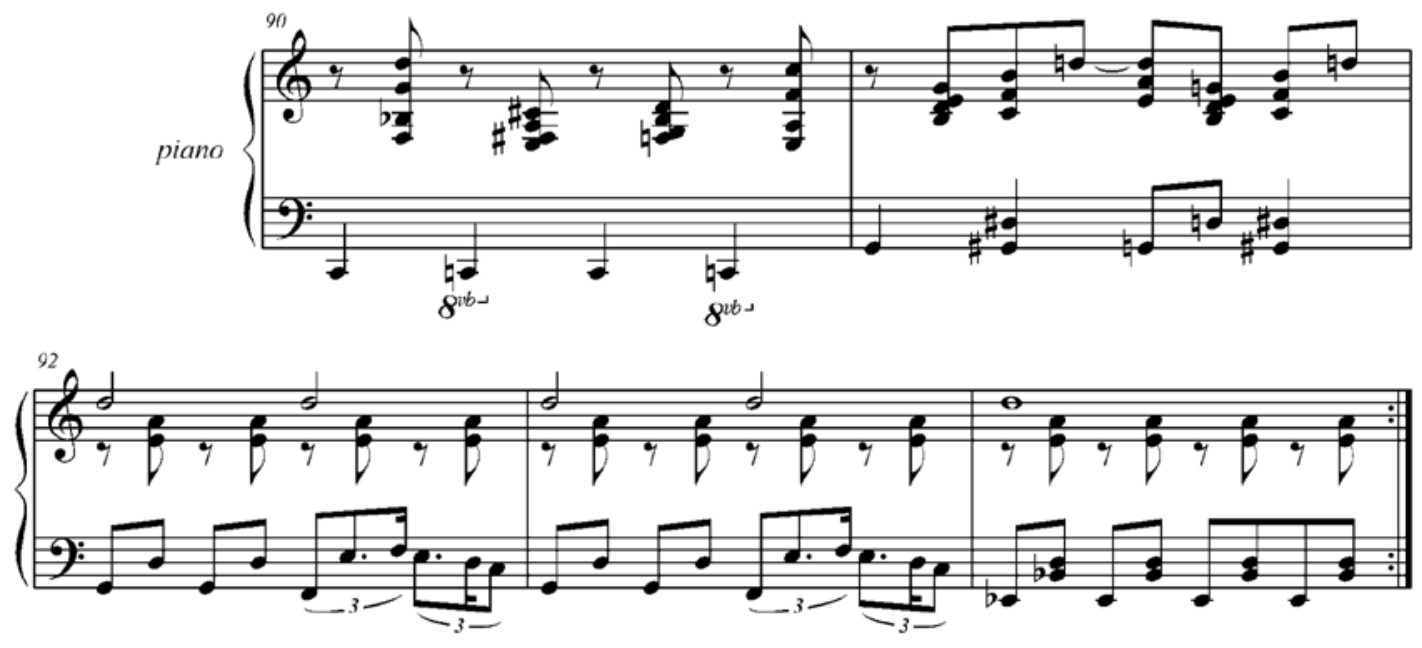

Ex.9 - Fox trot em Rimsky de Gilberto Mendes (c.90-94)

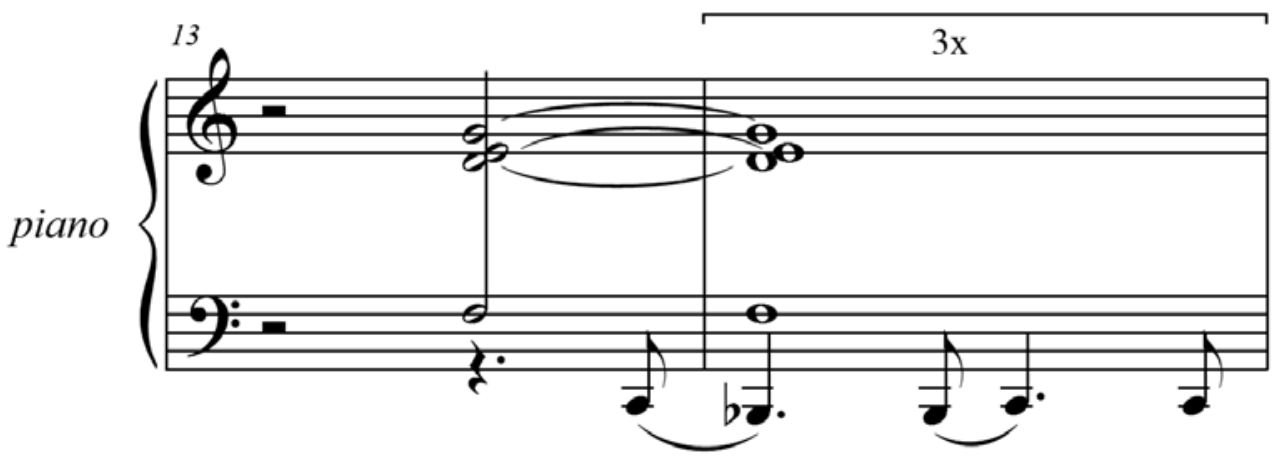

Ex.10 - Ritmo (Nordestino Brasileiro) em Rimsky de Gilberto Mendes (c.13-14)

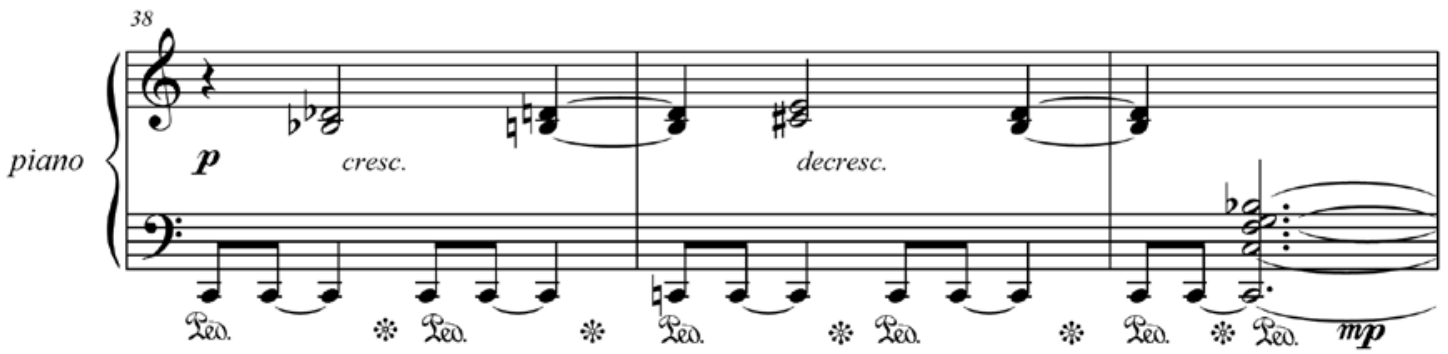

Ex.11 - Rock lento em Rimsky de Gilberto Mendes (c.38-40) 

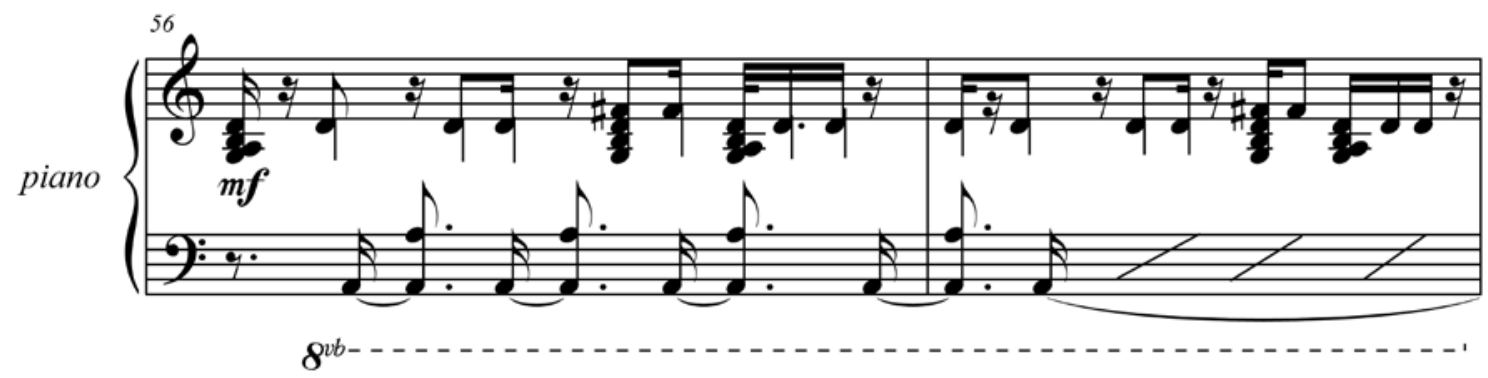

Ex.12 - Bossa Nova em Rimsky de Gilberto Mendes (c.56-57)

Viol.I

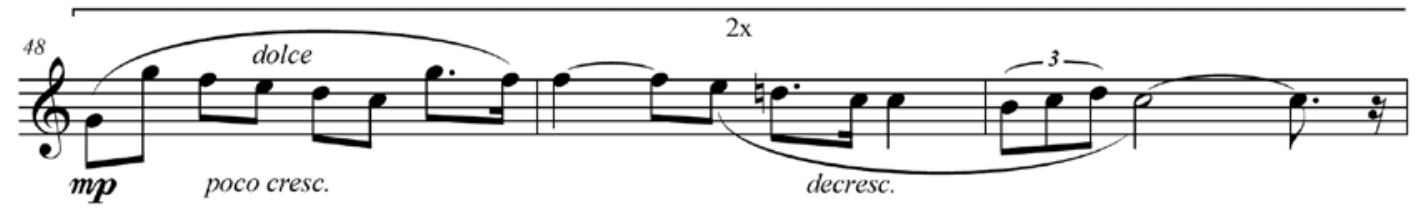

Ex.13 - Citação do Quinteto em Si bemol Maior para piano e sopros de Rimsky-Korsakov em Rimsky de Gilberto Mendes (c.48-50)

Viol.I
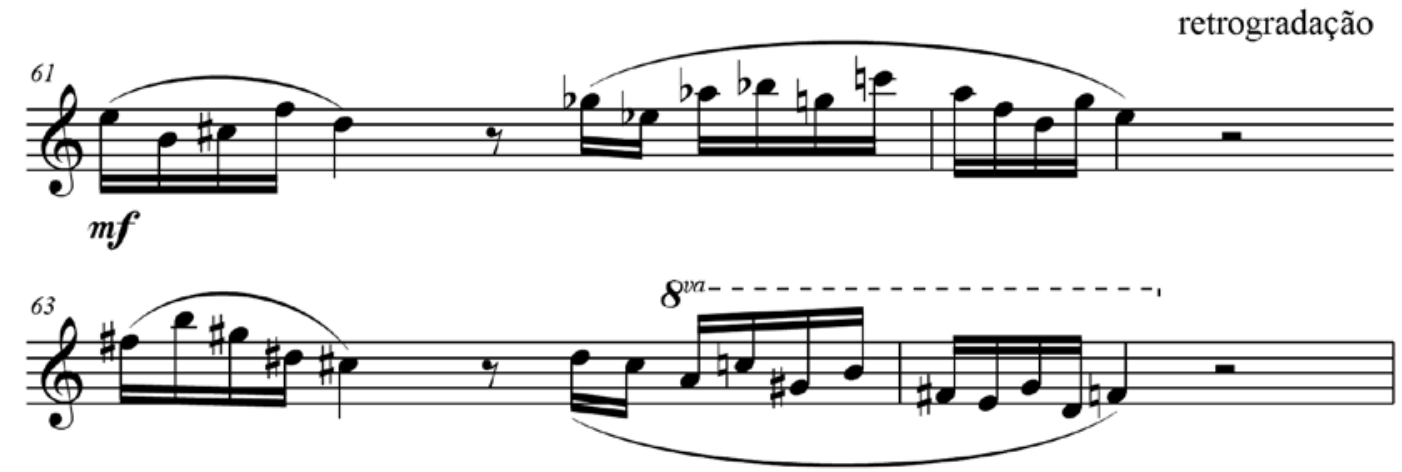

Ex.14 - Melodias derivadas da série em Rimsky de Gilberto Mendes (c.61-62)

Viol.I
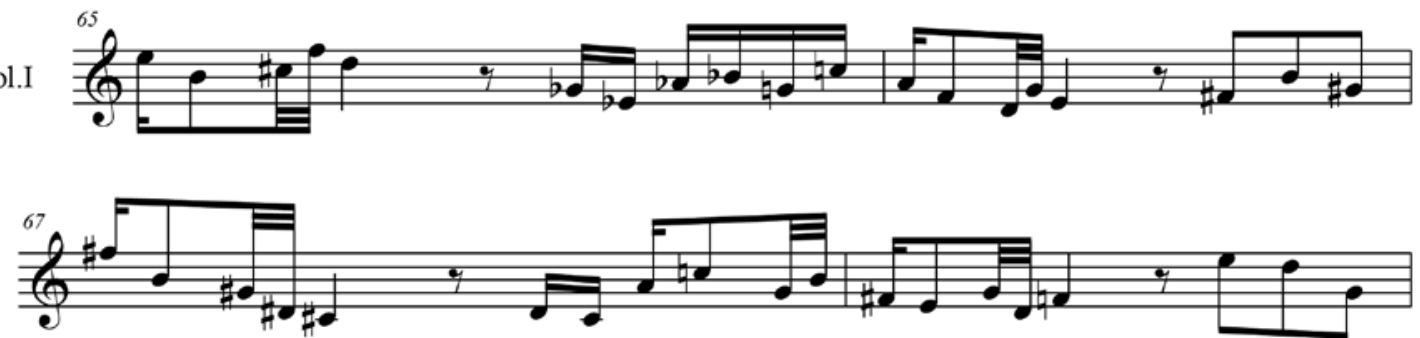

Ex.15 - Tango em Rimsky de Gilberto Mendes (c.69-72) 
Original (violino I, c.1-2)

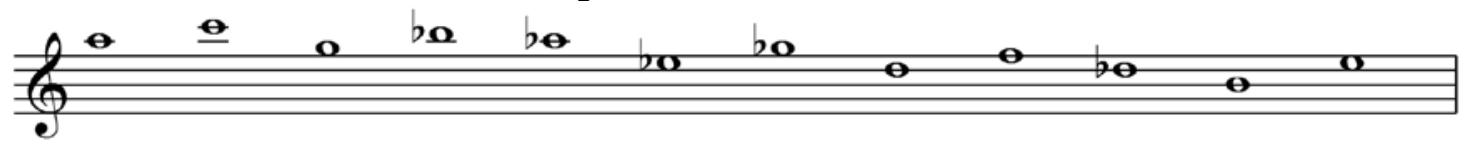

Inversão (violino I, c.12-13)

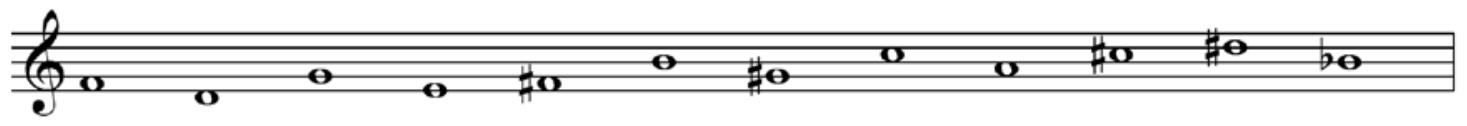

Retrogradação (violino II, c.28-29)

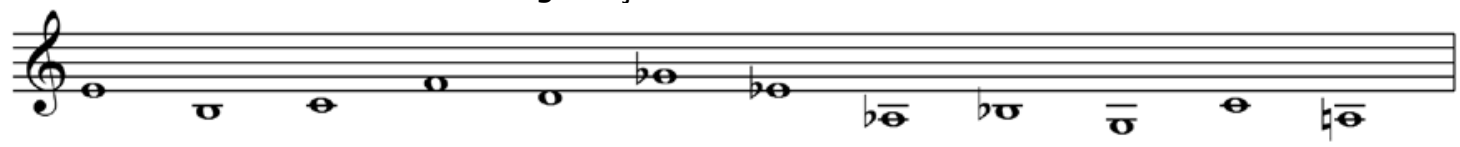

Inversão Retrógrada (viola, c.36-37)

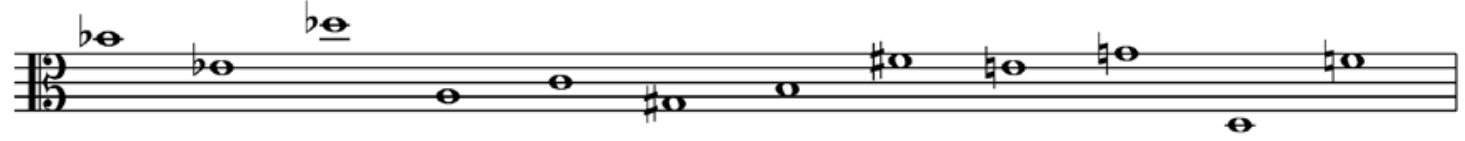

Ex.16 - A série e suas inversões em Rimsky de Gilberto Mendes

\section{Percurso da escuta em Rimsky de Gilberto Mendes}

0 percurso de escuta de Rimsky de Gilberto Mendes é detalhado abaixo, com a listagem dos traços existentes encontrados, sua localização por compasso e timing em cada uma das sete seções e recapitulação da obra:

\begin{tabular}{|l|l|l|}
\hline SEÇÃo I: & Part./compasso & CD/counter \\
\hline Apresentação da série original & $1-2$ & $00: 01-00: 07$ \\
\hline Transição & 3 & $00: 10-00: 24$ \\
\hline Acorde de sexta & 4 & $00: 25$ \\
\hline Motivo inspirado em Rimsky Korsakov & $4-5$ & $00: 26-00: 33$ \\
\hline Citação de Sheherazade & 6 & $00: 34-00: 40$ \\
\hline Oscilação (acorde de la m com 7ª, ${ }^{a},{ }^{1}{ }^{\text {a) }}$ & $8-10$ & $00: 40-00: 58$ \\
\hline SEÇÃo II: & & \\
\hline Inversão da série & & $01: 02-01: 08$ \\
\hline Evocação de ritmo brasileiro (piano e cordas) & $12-13$ & $01: 09-01: 49$ \\
\hline Citação de Sheherazade (piano) & $13-17$ & $01: 52-01: 57$ \\
\hline Citação de Sheherazade (violinol) & $17-18$ & $01: 59-2: 05$ \\
\hline Passagem livre com menção de Sheherazade & 19 & $02: 06-02: 19$ \\
\hline Minimalismo & $20-22$ & $02: 20-03: 30$ \\
\hline
\end{tabular}




\begin{tabular}{|l|l|l|}
\hline SEÇÃo III: & & \\
\hline Retrogradação da série & $28-29$ & $03: 33-03: 42$ \\
\hline Passagem livre no piano & $30-31$ & $03: 42-03: 49$ \\
\hline Ritmo (cordas) & $32-34$ & $03: 51-04: 07$ \\
\hline
\end{tabular}

\begin{tabular}{|l|l|l|}
\hline SEÇÃo IV: & & \\
\hline Inversão retrógrada da série & $35-37$ & $04: 08-04: 18$ \\
\hline Ritmo de rock lento & $38-40$ & $04: 19-04: 28$ \\
\hline Música de cinema (apoiada em acorde de 4. e $^{\text {a }}$.) & $40-47$ & $04: 30-05: 00$ \\
\hline Citação do Quinteto para piano e sopros & $48-50$ & $05: 01-05: 25$ \\
\hline Melodia no piano & $51-54$ & $05: 26-05: 53$ \\
\hline Início de bossa nova no piano & $55-57$ & $05: 54-06: 09$ \\
\hline Elementos inspirados em R. Korsakov + bossa nova & $58-59$ & $06: 10-06: 26$ \\
\hline Finalização de bossa nova no piano & 60 & $06: 27-06: 34$ \\
\hline Melodia derivada da série + rock lento (piano) & $61-68$ & $06: 35-07: 35$ \\
\hline Tango (melodia derivada da série + ritmo/tango) & $69-72$ & $07: 35-08: 24$ \\
\hline Bossa nova + Sheherazade transformada & $73-76$ & $08: 24-08: 52$ \\
\hline Acorde menor c/ figura de improviso como clichê & $77-79$ & $08: 53-09: 03$ \\
\hline
\end{tabular}

\begin{tabular}{|l|l|l|}
\hline SEÇÃo V: & & \\
\hline Trecho atonal + rock lento (piano) & $80-94$ & $09: 04-11: 03$ \\
\hline
\end{tabular}

\begin{tabular}{|l|l|l|}
\hline SEÇÃO VI: & & \\
\hline Cadenza p/piano (com fragmento de bossa nova) & $95-103$ & $11: 04-11: 46$ \\
\hline & & \\
\hline RECAPITULAÇÃO: & & $11: 47-11: 52$ \\
\hline Tango (harmonia e ritmo) & $102-104$ & $11: 53-12: 02$ \\
\hline Ritmo (cordas) & $105-106$ & $12: 03-12: 13$ \\
\hline Bossa nova & $107-108$ & $12: 14-12: 49$ \\
\hline Melodia derivada da série + rock lento (piano) & $109-116$ & $12: 50-13: 09$ \\
\hline Lirismo & $117-120$ & $13: 10-13: 28$ \\
\hline Final sem conclusão (acomp. de rock lento/piano) & $121-123$ & \\
\hline
\end{tabular}




\section{Análise da obra: detalhamento da análise pormenorizada dos procedimentos}

\subsection{A citação e a sintaxe}

Rimsky foi escrita por encomenda de Philip Rathé, diretor do Spectra Ensemble, da Bélgica, para ser estreada em 2000 em um Festival da Rússia. Tem, portanto, um projeto extramusical de homenagem ao compositor russo Nikolai Rimsky-Korsakov (1844-1908). As citações de temas em Rimsky têm um intuito evocativo e referem-se às obras de Rimsky-Korsakov: Sheherazade e Quinteto em Si bemol Maior para piano e sopros. Para a verificação do original, recorremos à sua redução para piano a duas mãos. Observemos a melodia que Korsakov introduz no recitativo de Sheherazade, apresentado pelo solo de violino (Ex.17).

Em seguida, observemos a $1^{\text {a }}$. citação de Korsakov em Mendes (c.6). Veremos que a utilização desta como uma singularidade exige uma solução de percurso (na medida em que pode elaborar saídas feitas por inferências locais). Inserida dentro de um sistema atonal/tonal (cuja série o corrobora) sai dessa ambiência ambígua e converge para a tonalidade usada por Korsakov (Ex.18).

Portanto, é importante notar que a melodia da "Sheherazade de Mendes" é finalizada pela nota ré e não mi como em Korsakov. Em Korsakov encontramos uma continuidade. Em Mendes há uma descontinuidade e uma interrupção.

Outro exemplo neste sentido é a citação do Quinteto em Si bemol Maior para piano e sopros de Korsakov (Ex.19).

Este trecho de Korsakov acima demonstrado aparece citado em Mendes e com repetição idêntica (diferentemente do trecho de Korsakov). Encontramo-lo entre o trecho onírico (que o autor denomina de música para cinema (c.40-47)) e um tema lírico feito pelo piano (c.51-55). Podemos notar

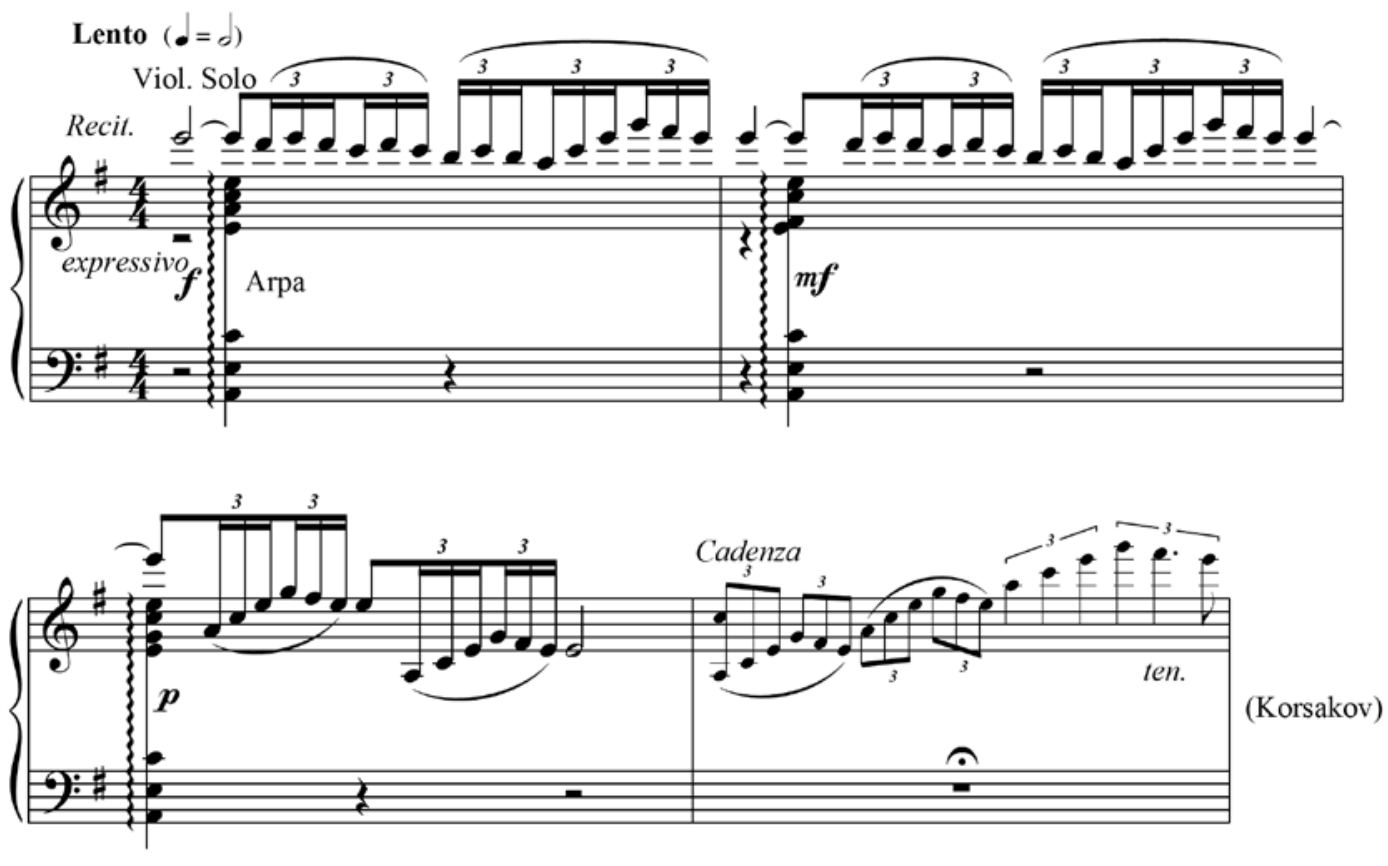

Ex.17 - Recitativo em Sheherazade de Rimsky-Korsakov (c.14-15)

viol. I

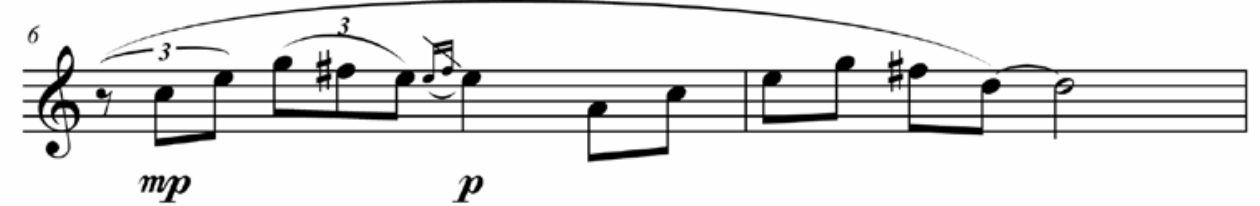

(Mendes)

Ex.18 - Citação de parte do tema de Sheherazade de Rimky-Korsakov em Rimsky de Gilberto Mendes (c.6-7) 


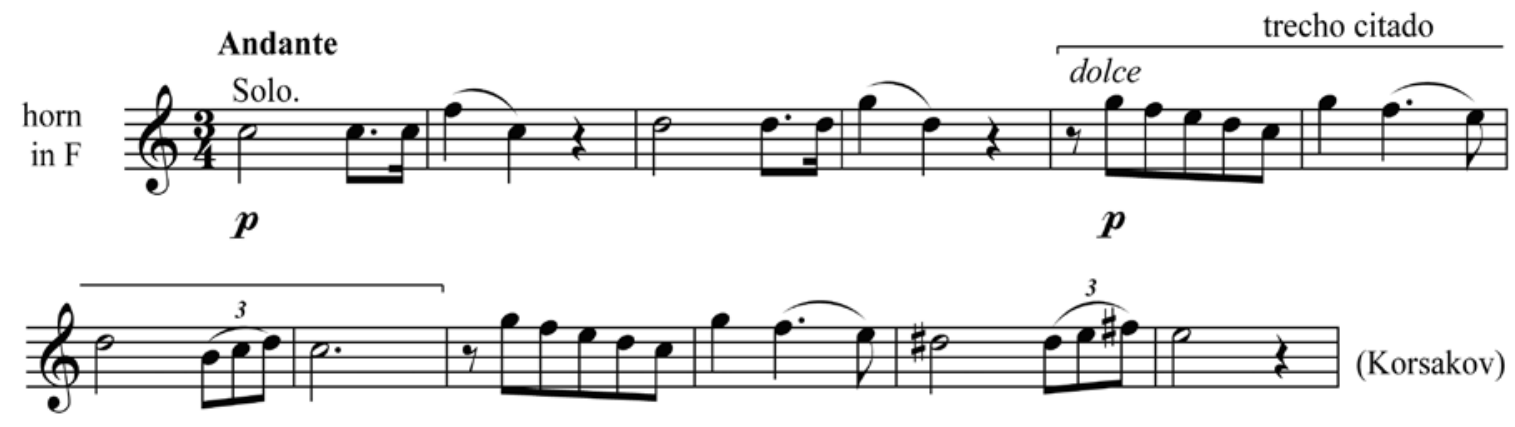

Ex.19 - Solo de trompa no II Movimento do Quinteto em Si bemol Maior para piano e sopros de Rimsky-Korsakov (c.5-8)

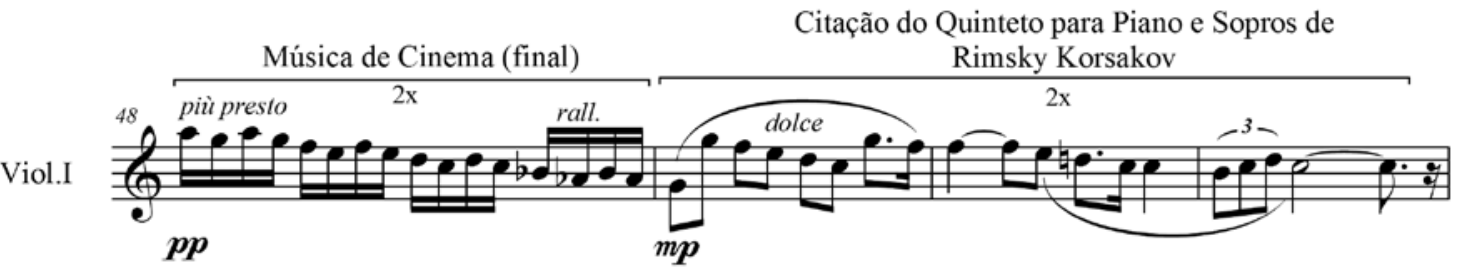

Ex.20 - Citação do Quinteto em Si bemol Maior para piano e sopros de Rimsky-Korsakov em Rimsky de Gilberto Mendes (c.49-51)

que estas são diferentes concepções que agora se tornam equalizadas, convivendo pacificamente (p.8-11) (Ex.20).

0 que resulta diferente então, são as sintaxes como concepções absolutamente opostas: a de Korsakov é teleológica, enquanto que a de Mendes é casual'.

Outro ponto importante a frisar é que se a composição de Mendes visa realizar uma homenagem, a citação não pode ser irônica. A finalidade da citação é evocar Sheherazade, o Quinteto em Si bemol Maior para piano e sopros de Korsakov e não desfigurá-la, isto é, Mendes pretende torná-la audivel, propiciar o reconhecimento de maneira lúdica, como evocação, fazendo um apelo à memória, para produzir efeitos de verdade. Já a erudição enciclopédica referente ao Quinteto em Si bemol Maior não configura a certeza de ser efetivada com a mesma eficiência.

Outros trechos evidenciam o aparecimento do mesmo tema de Sheherazade transformados pela exigência casual da sintaxe em Rimsky de Gilberto Mendes (c.17-22). Aqui há também modificações efetuadas nos confins da citação (início e fim) e inserção de elementos livres que confluirão em novas descontinuidades, cuja linha de fronteira em seu final é estendida.

É assim que através da utilização de materiais fragmentados constituiu-se essa sintaxe tipificada como pluralista e inclusiva. A sintaxe é desconstruída em prol da figuralidade onde as imagens preponderam dando lugar à busca de novas sensações. Inverte-se a primazia da forma sobre o conteúdo: agora é o conteúdo que determina o processo composicional, possibilitando várias associações a diferentes estados afetivos. A fragmentação efetuada na obra se realiza através de um procedimento duplo: promove o declínio da inteireza e da continuidade e ao mesmo tempo propicia a unificação na medida em que torna as frases musicais equalizadas onde as possiveis conexões não revelam seus pontos de ligação, tornando-os imperceptíveis. 0 uso do fragmento não exige desenvolvimento, não se submete a nenhuma forma, prevalecendo o prazer do perder-se. Não há mais estruturação por regras sistemáticas. 0 tempo torna-se simultânea e paradoxalmente não-linear, sem se opor à continuidade, sem adotar a causalidade. Esta impressão é possibilitada pela admissão de fragmentos diferenciados que promovem a perda da totalidade e tornam-se indiferenciados em sua coexistência, desafiando a noção de centro.

Segundo Calabrese (1988), a citação pós-moderna tornase um elemento de imprecisão. Nega a precisão e a ordem, valorizando o conceito de "vago" (p.178). Como vimos, com esse tipo de citação, passado e presente tornam-se sincrônicos, improváveis. 0 passado necessitará sempre ser modificado pelo presente, reatualizado, uma vez que precisa ser inserido em um novo contexto. Torna-se um desafio à arte aurática, na medida em que se traduz num ready-made, num simulacro e numa contestação do estatuto da arte enquanto originalidade e subjetividade. Não existe preocupação com a precisão e sim com a evocação da memória afetiva transposta imprecisamente e adaptada dentro da linha sonora em curso. A citação em Mendes não é perspícua, não se importando com a autenticidade da fonte. Esta é uma característica importante que joga com a relação entre o verdadeiro e o falso. Apesar de imprecisa, necessita apenas da existência do saber enciclopédico do ouvinte, como mostrado nos pares de exemplos 
Ex.21a-Ex.21b e Ex.22a-Ex.22b.

0 recurso do corte verificado através da mudança brusca (contraste) de andamento e dinâmica ( $m p / f$; transmutação de semínima 60 para 120) corrobora a existência da subtração das conexões decorrente da opção pelo procedimento inclusivo (o que permite contribuir para obscu- recer a natureza do "discurso") (Ex.23).

Verificamos que Mendes se apropria do gesto de Korsakov dentro de uma concepção de improvisação idiomática introduzindo elementos (ritmico-melódicos) rapsódicos transformados, que se apresentam como figuras de clichê características da improvisação (c.78,

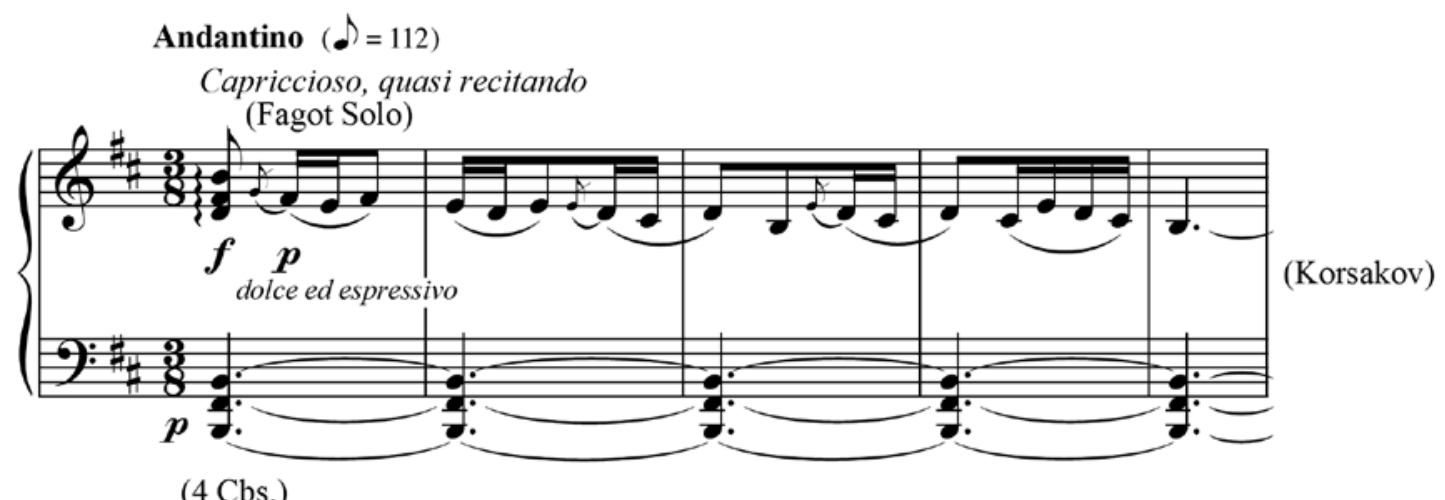

Ex.21a - Motivo apresentado pelo fagote no II movimento de Sheherazade de Rimsky-Korsakov (c.5-9)

viol. I

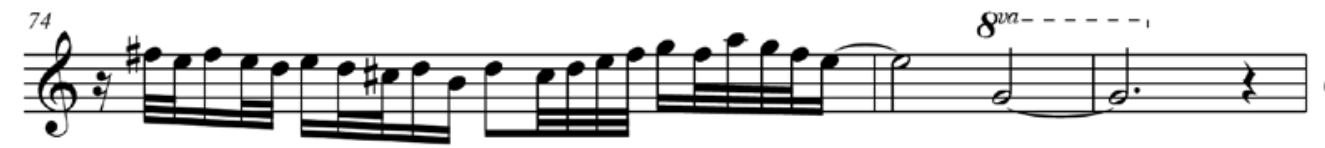
(Mendes)

Ex.21b - Motivo de Korsakov (mostrado acima) transformado em Rimsky de Gilberto Mendes (c.74-76)

(A) viol.
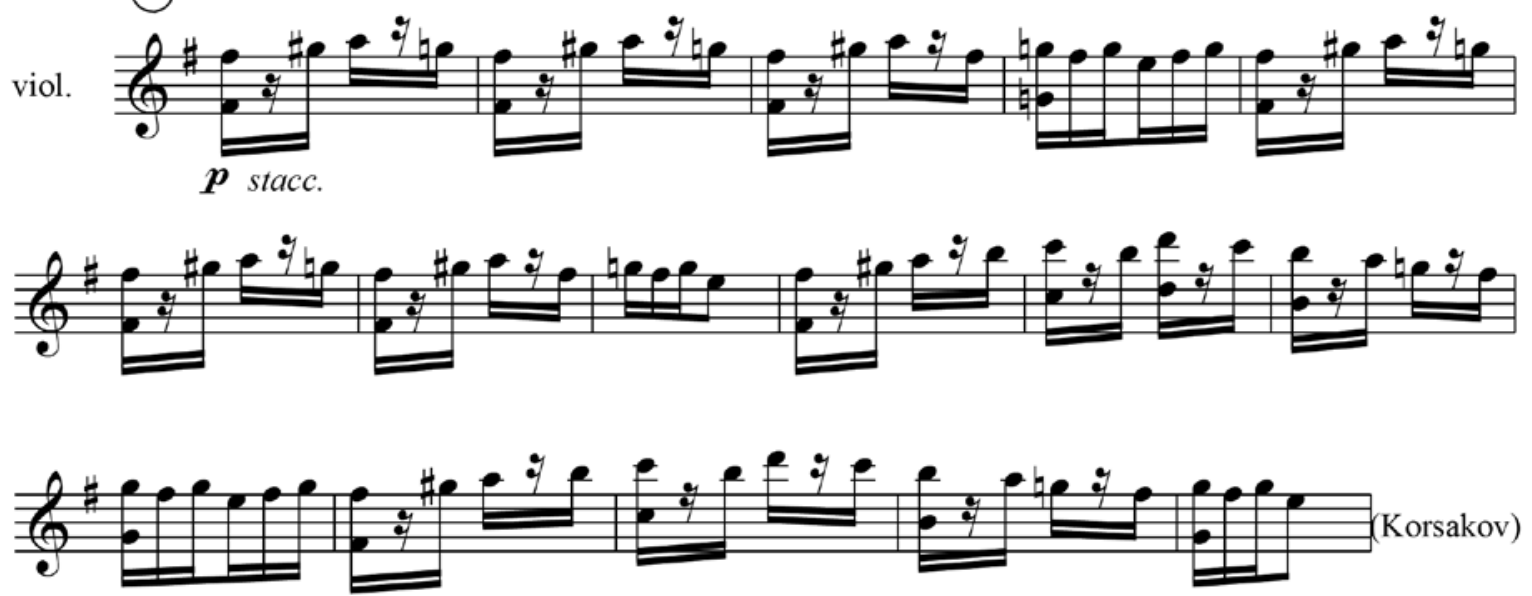

Ex.22a - Motivo melódico-ritmico de Korsakov (IV Movimento de Sheherazade, c.54-69)

viol. I

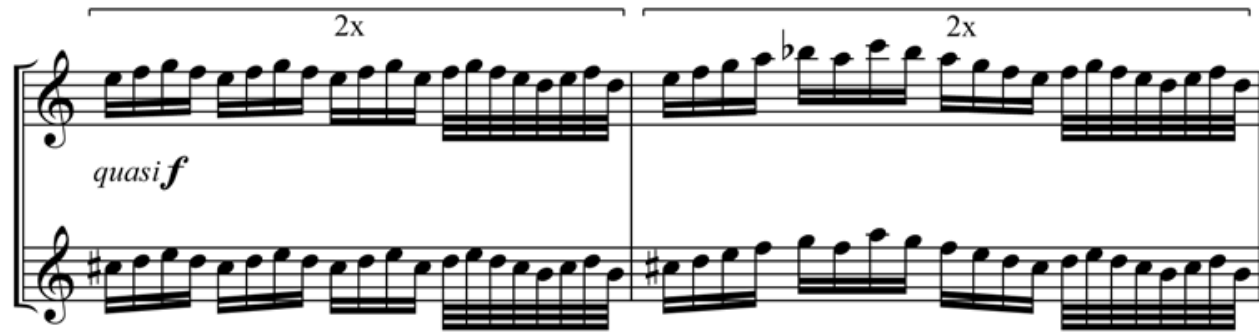

(Mendes)

viol. II

quasif

Ex.22b - Motivo de Korsakov (mostrado acima) transformado em Rimsky de Gilberto Mendes (c.58-59) 
p.17). A utilização do recurso do fragmento revela o retorno à espontaneidade (ao eximir-se dos antigos códigos de coerência da linguagem), configurando-se como um jogo que ao mesmo tempo contém e se livra das regras, desempenhando na obra uma desenvoltura que afirma o acaso. A sintaxe submete-se às imposições do desejo, da sensação, do sentimento.

Em resumo, a heterogeneidade empregada desfaz a diferença entre os materiais. Em Rimsky, o uso da citação e das referências como fragmentos autônomos produz uma sintaxe nômade, evitando as conexões, o centro e a ordem, resultando num perder de vista dos grandes quadros de referência.

\subsection{A série de Mendes como paródia pós- moderna}

Sabemos que a série básica criada por Schoenberg, portadora de 12 sons distintos e irrepetíveis constituiu uma regra rigorosa de controle da composição musical dodecafônica.
Em Rimsky, a série introduzida por Gilberto Mendes subverte essa intenção. Mendes inicia sua obra sem indicação de tonalidade sugerindo uma audição atonal, tornando-a, entretanto, ambígua através da utilização predominante de intervalos consonantes. Constatamos, portanto, logo de início, uma intervenção do compositor que descarta a representação rígida da série convencional para nos apontar uma nova singularidade em relação àquela.

Ao não se constituir como série estritamente dodecafônica, revela sua relação paródica com a arte do passado, sendo esta uma forte característica de sua linguagem. Sob este ponto de vista, sua postura implica a crítica ao Modernismo tardio através da inclusão deste em sua linguagem, mas com a série modificada, reapropriada. A série de Mendes destitui-se de parte de seus pressupostos teóricos intransigentes (daquela de Schoenberg), possibilitando a contaminação de sua pureza, mesclando o tonal com o atonal. Examinemos de perto suas características no Ex.24.

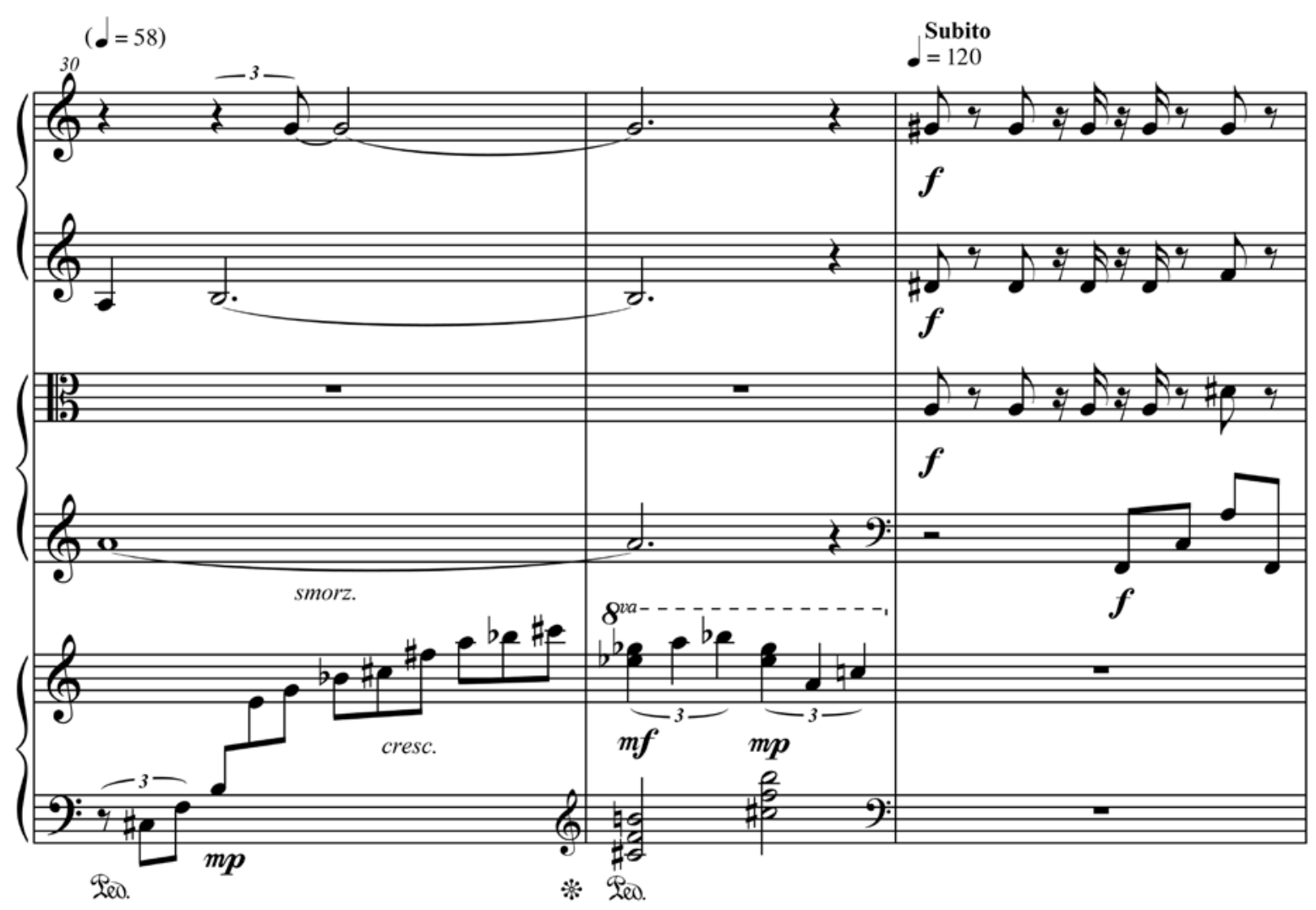

Ex.23 - Recurso de corte através de mudança brusca de andamento e de dinâmica em Rimsky de Gilberto Mendes (c.30-32)

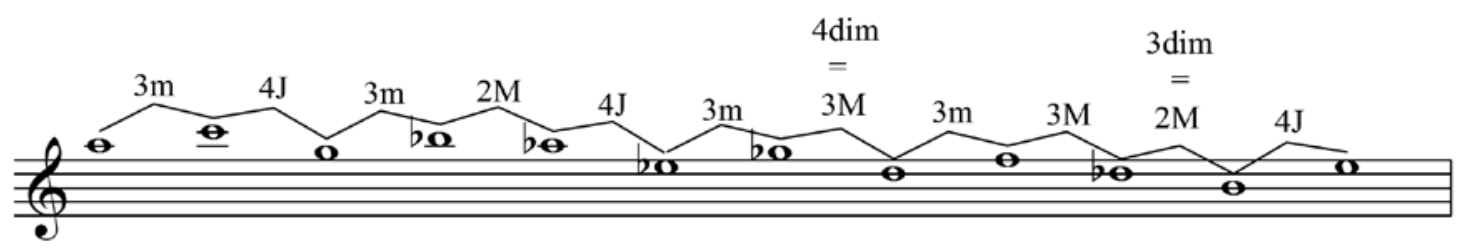


Verificamos a ocorrência de:

- 4 intervalos de $3^{\mathrm{a}}$. $\mathrm{m}$;

- 3 intervalos de $4^{\mathrm{a}}$. J;

- 2 intervalos de $3^{\text {a }} . \mathrm{M}$;

- 1 intervalo de $2^{\text {a }}$. M.

A série de Mendes despreza, portanto, o potencial intervalar que (em Schoenberg) preconizava a emancipação da dissonância e o afastamento da tonalidade. Não há trítonos, nem intervalos de $7^{\text {a. }} 9^{\mathrm{a}}{ }^{\mathrm{a}}, 2^{\mathrm{a}}$.m. Não é anti-tonal, possui duas terças menores em seguida (propiciadoras de enunciação de arpejos). Enfim, a série de Mendes é distorcida, ambígua, ambivalente e percorre o caminho contrário ao de Schoenberg. A série usada por Mendes preserva as características formais da série dodecafônica (doze notas irrepetíveis e suas inversões) subvertendo ao mesmo tempo seu conteúdo (predominância de intervalos consonantes portadores de possibilidades tonais). Ao mudar o conteúdo desta, verificamos que a intenção de Mendes não é de se ater à pureza do pensamento original de Schoenberg. Ao contrário, Mendes mantém as formas reflexas da série (Ex.25), com vistas à criação de uma ilusão perceptiva, que a torna híbrida, provocando sua desestabilização.

Se Schoenberg objetivou a busca pelo singular, eliminando a noção de graus, de funcionalidade e hierarquia promovendo a escuta da nota individualizada, Mendes procura ativar o reaparecimento de configurações reconhecíveis. 0 conteúdo de Mendes apóia-se no significado, na aceitação e no resgate da consonância, de mais fácil assimilação. Desta forma, a série de Mendes se ressemantiza, ironicamente, deslocando-se da abstração para introduzir posteriormente, a possibilidade de configurações melódicas (Ex.26). 0 autor utiliza a série, desconstruindo concomitantemente o percurso de Schoenberg, reinterpretando-0. Utiliza-se dos procedimentos da vanguarda para criticá-la, mostrando-se avesso à teoria.

Vimos que a série de Mendes não sendo antitonal possibilita uma configuração melódica que se generaliza, na medida em que é reutilizada ao se somar com a referência introduzida pela rítmica do tango, propiciando seu reconhecimento pela escuta. Incorpora, desta forma, a utilização de códigos populares: (Ex.27).

A série de Mendes contesta a originalidade, recontextualizando-a. Como no dizer de HUTCHEON (1991), é reverente e irreverente ao mesmo tempo, fazendo coabitar a noção de sacralização e dessacralização, autoridade e transgressão, continuidade e mudança. A nosso ver, habilita, contudo, o retorno daquilo que foi recalcado pelo modernismo (a compreensibilidade através do que é cantável, a impressão de tonalidade, a memorização). Ela comporta, contudo, uma novidade que, como tal, exige a familiaridade com antigas convenções para que se possa averiguar sua discordância dos cânones prevalecentes e consequentemente invocar as considerações de intenção do autor, condição que o receptor pós-moderno não possui, por viver numa época em que o consumo imediato e o hedonismo não priorizam o conhecimento e a teoria. A compreensão da ironia pressupõe uma grande cultura por parte do ouvinte ${ }^{12}$.

A série de Mendes questiona o ideal totalizante modernista, a tirania teórica, a racionalidade, o purismo, onde o autor procura propor uma abertura do texto cujo novo sentido evita prescrições, mas resgata fórmulas usadas.

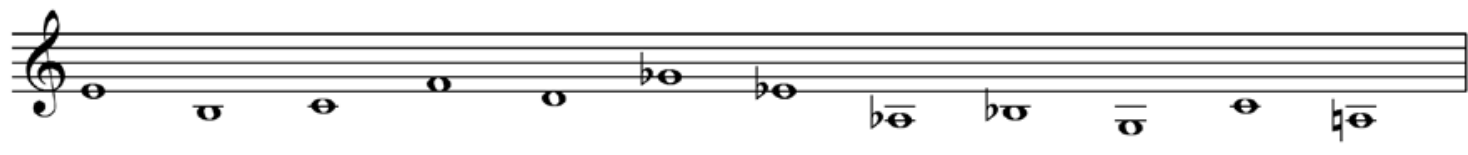

Ex.25 - Retrogradação da série em Rimsky de Gilberto Mendes

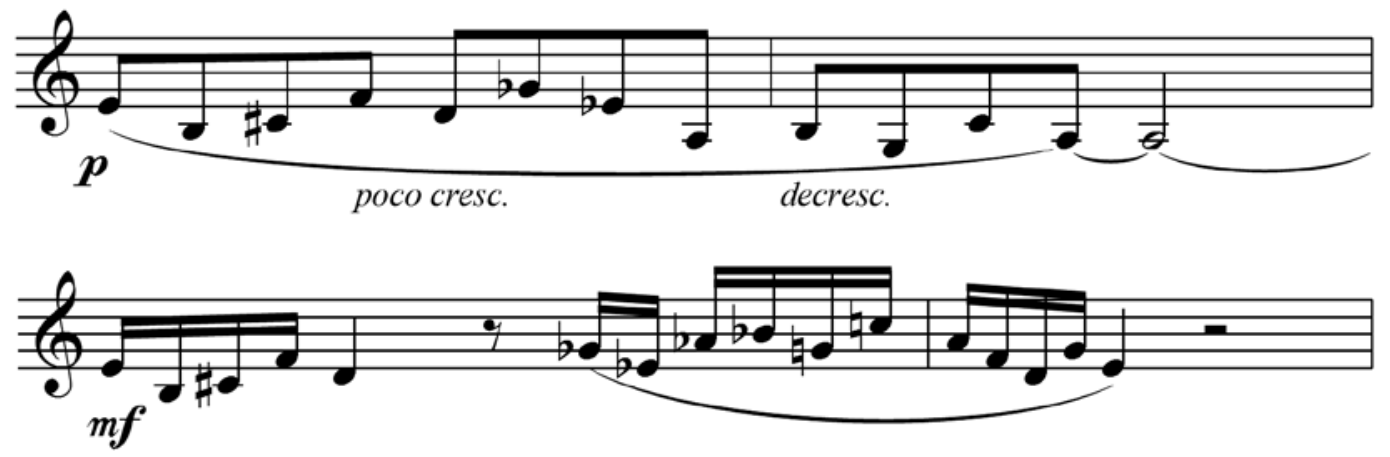

Ex.26 - Melodias derivadas da série em Rimsky de Gilberto Mendes (c.28-29 e c.61-62) 

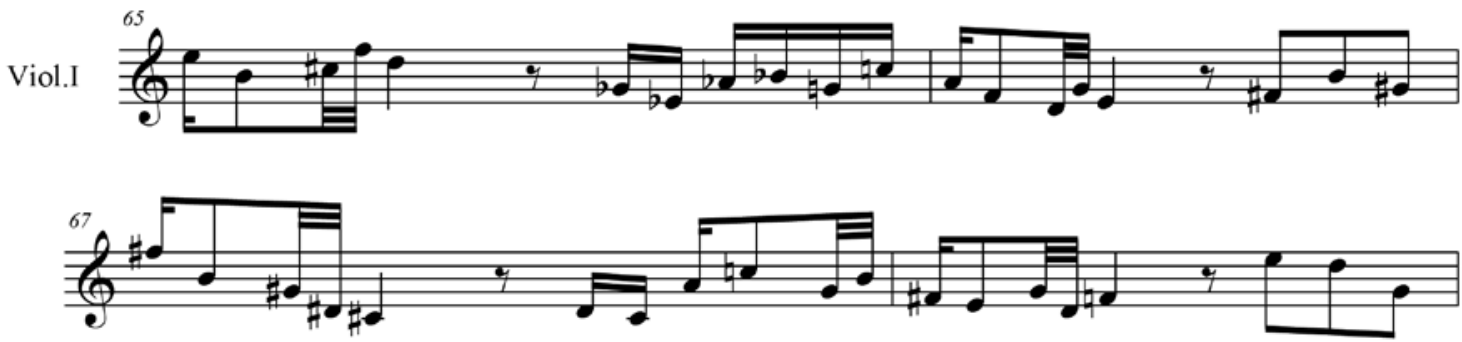

Ex. 27 - Tango derivado da série em Rimsky de Gilberto Mendes (c.65-68)

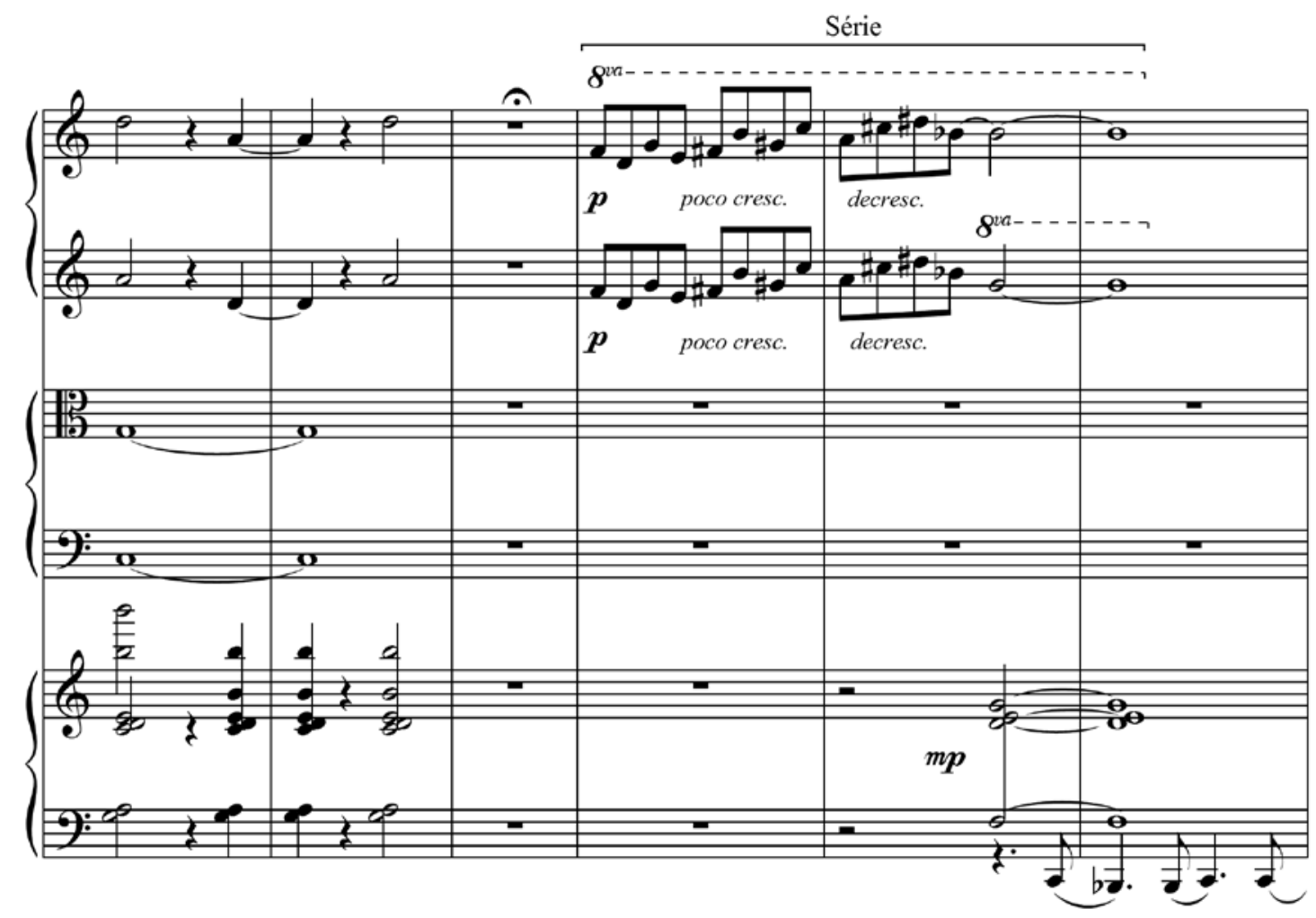

Ex.28 - Série em Rimsky de Gilberto Mendes. (c.12)

A série de Mendes é o elemento de diferença que distingue o modernismo do pós-modernismo, por desestabilizar a intenção (dodecafônica) de sons isolados e da não repetição, fazendo o percurso inverso do de Schoenberg. Ela é introduzida sempre depois de uma fermata ou de um rallentando, desconectada, portanto, do episódio anterior, incrementando a descontinuidade da sintaxe (Ex.28). ${ }^{13}$.

\subsection{Pós-Moderno e a atenuação das distinções - música popular/música erudita:}

Rimsky apresenta a inserção de ritmos e harmonias características da música popular brasileira procurando viabilizar o cruzamento de linguagens tradicionalmente opostas, impossivel em períodos históricos precedentes. Intenta contrapor-se ao purismo, procurando não as in- compatibilizar, não imprimir uma visão dualista entre 0 erudito e o popular. Pretende realizar para isto conexões consideradas antes impossiveis, recusando a hierarquia e a hegemonia entre alta e baixa cultura.

Em sua autobiografia (1994) Mendes registra sua natureza despreconceituosa que o acompanha desde a infância, reconhecendo o alto nivel alcançado pela música popular urbana da canção norte-americana e europeia dos anos 30 e 40 e seu entrosamento com a música culta, que ele denomina ser um verdadeiro lied moderno. Pensando desta forma é que o autor utiliza-se amplamente do elemento popular em suas composições. Baseando-se em suas memórias perceptuais, permite "contaminações" que abolem todas as proibições. 
Em Rimsky verificamos o uso de superposições e "fusões" entre o popular e o clássico verificadas nos elementos inspirados em Rimsky-Korsakov + bossa nova (c.58-60; Ex.29). Outras fusões são encontradas na série transformada em melodia + rock lento no piano (c.6168); melodia de Sheherazade transformada + bossa nova (c.74-79); trecho atonal + rock lento (c.80-94); melodia da série + rock lento em recapitulação (c.109112); melodia em progressão + rock lento (c.117-120).

Mendes não só incita ao reconhecimento. A urdidura do trecho atonal (Ex.30) em meio à sua textura abstrata ${ }^{14}$ juntamente com a inclusão de elementos de referência (verificadas nos ritmos feitos pelo acompanhamento no piano de rock lento) ao mesmo tempo as obnubila (c. 80-94).

0 tipo de linguagem utilizada em Rimsky, portanto, utiliza-se da junção de elementos de origens diferentes ${ }^{15}$, cujo procedimento pode ser caracterizado como inclusivo e democrático. Tal medida pressupõe a intenção de um caráter de tolerância e diversidade como tentativa de questionamento das distinções.

\section{Características pós-modernas em Rimsky de Gilberto Mendes}

Sumariando a ocorrência dos traços pós-modernos em Rimsky, constatamos as seguintes propriedades:

1. Série defectiva;

2. Fragmentação, heterogeneidade, descontinuidade, justaposição de estilos;

3. Impureza; hibridismo; contaminações;

4. Ironia:

5. Ênfase nos processos primários, inconscientes (evocação, desejo, imagem);

6. Paródia;

7. Ambiguidade (questionamento e conciliação); (reverência e dessacralização);

8. Apropriação, citação distorcida; imprecisão;

9. Ausência de unidade; ausência de conexões;

10. Estesia (ênfase nas sensações);

11. Retorno à melodia; caráter melífluo (que impressiona agradavelmente);

12. Inexistência de desenvolvimentos musicais puros;

13. Volta ao conteúdo; busca de significados;

14. Atemporalidade;

15. Consciência histórica vista como pluralismo, como presente sincrônico;

16. Simplicidade;

17. Uso de estilemas e estereótipos;

18. Processo composicional determinado pelo material;

19. Ênfase na superfície;

20. Incerteza entre o verdadeiro e falso;

21. Antiacademismo; contra o rigor e a exatidão; contra proibições;

22. "Moderno" deixa de ser um substantivo para tornarse um estilo (trecho atonal);

23. Sintaxe casual, antinarrativa;

24. Imersão (ao invés de distanciamento);
25. Caráter lúdico;

26. Proposta de inclusão da música culta e da música popular;

27. Tendência predominante de exclusão da seriedade ${ }^{16}$, hedonismo;

28. Anarquia, procedimento assistemático;

29. Repetições não variadas.

\section{Conclusão}

Utilizamos as evidências do exame feito por Omar Calabrese em seu livro "A Idade Neobarroca" (CALABRE$\mathrm{SE}$, 1988) sobre estética e teorias contemporâneas para o esclarecimento das implicações do gosto e do pensamento dito pós-moderno que incidem na forma e na adoção de uma epistemologia anárquica. É importante realçar a advertência de Calabrese sobre a citação como um modo tradicional de construir um texto que existe em todas as épocas e estilos que, no caso pós-moderno, ele desconsidera a computação da quantidade de citações como um critério relevante para sua caracterização. Para Calabrese, nem a quantidade das citações nem o ecletismo são características estritamente pós-modernas. Em meio às divergências teóricas existentes, o ecletismo (ou pluralismo) tem sido apontado como a principal característica pós-moderna. Mas que tipo de ecletismo?

Em feição pós-moderna, esse ecletismo não só institui uma objeção da pureza e do elitismo, mas conjuga-os à ideia de desconstrução (derrideana) do significado que abole a noção de origem e de verdade e deságua na ideia de que só existem significantes, decorrendo daí a possibilidade de interpretações incessantes, onde todas se afirmam válidas. Se como já foi dito, a maioria das caracteristicas atribuidas ao pós-moderno já foram anteriormente encontradas em períodos anteriores, o que o distingue de outras épocas é uma aposta na proscrição da unidade estrutural e da teleologia em favor da descontinuidade e da atemporalidade possibilitados pela anomia da sintaxe. Não há mais uma direcionalidade visando pontos focais, oposições, pontos culminantes, não há mais a imposição do cânone modernista de proibições, nem a elaboração de um "discurso" sistemático, mas uma errância, uma ausência de fundamento, de abandono da epistemologia e da teoria. Verificamos, portanto, a suspensão do juízo em prol da casualidade, da arbitrariedade, e da liberdade ilimitada. Colagem e citação subtraem as conexões e a citação que remete à concepção de autoria (ou seja, que tem como parâmetros a originalidade, a autenticidade e a autoridade) é que é criticada. Dessa forma a citação, através do procedimento da apropriação, por realizar uma alteração, necessita subverter o contorno melódico dirimindo a diferença das estruturas contraditórias. Não há mais sucessão temporal, porém, um contínuo de justaposições de materiais e estilos de diferentes épocas que através de sua apropriação resultam presentificados, indiferenciados, homogeneizados. Como decorrência, a fragmentação resulta numa compilação de descontinuidades cuja autonomia dos momentos se traduz, segundo 
Sheherazade Transformada + Bossa-Nova:

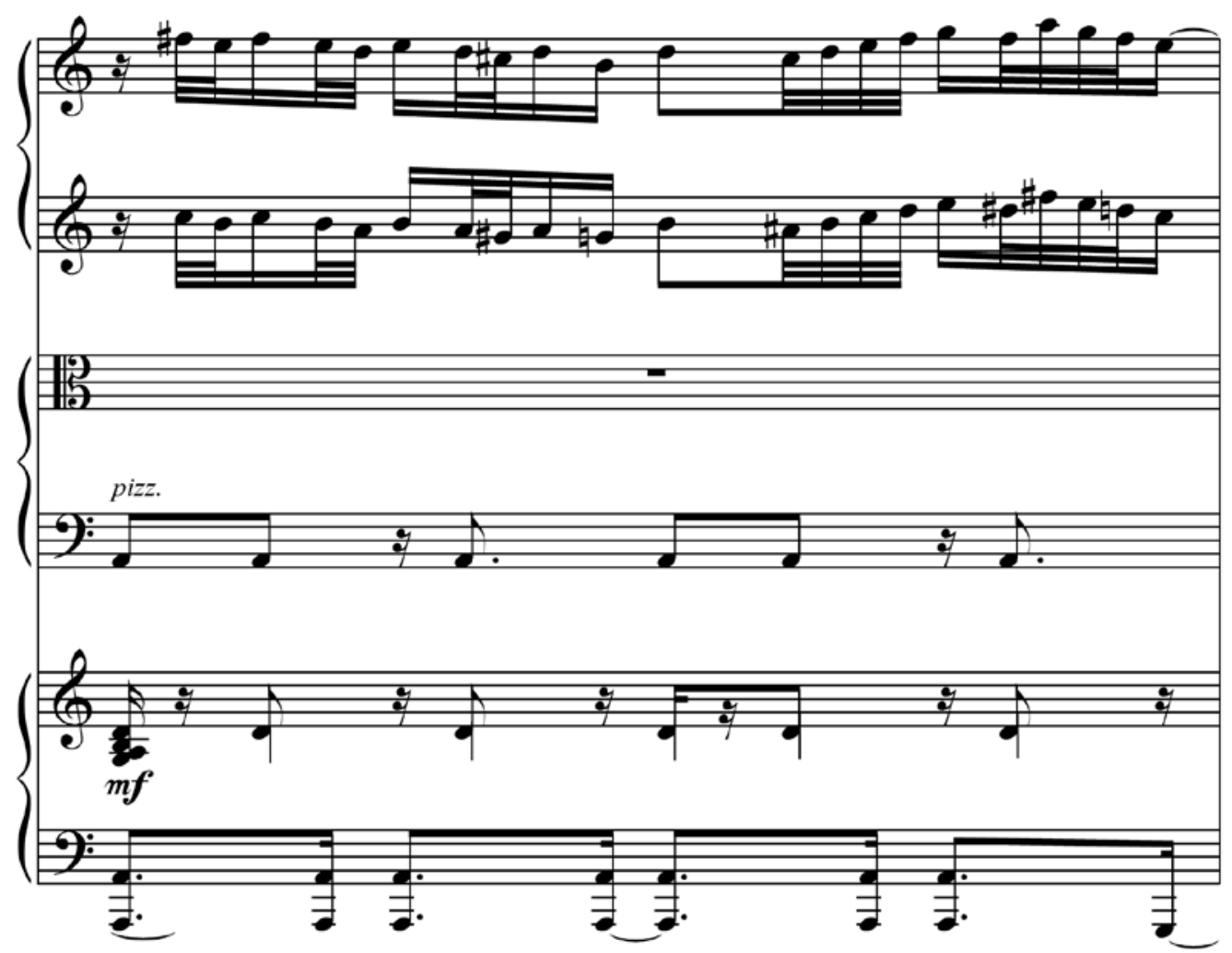

Ex.29 - Sheherazade transformada+ Bossa-Nova em Rimsky de Gilberto Mendes (c.74)

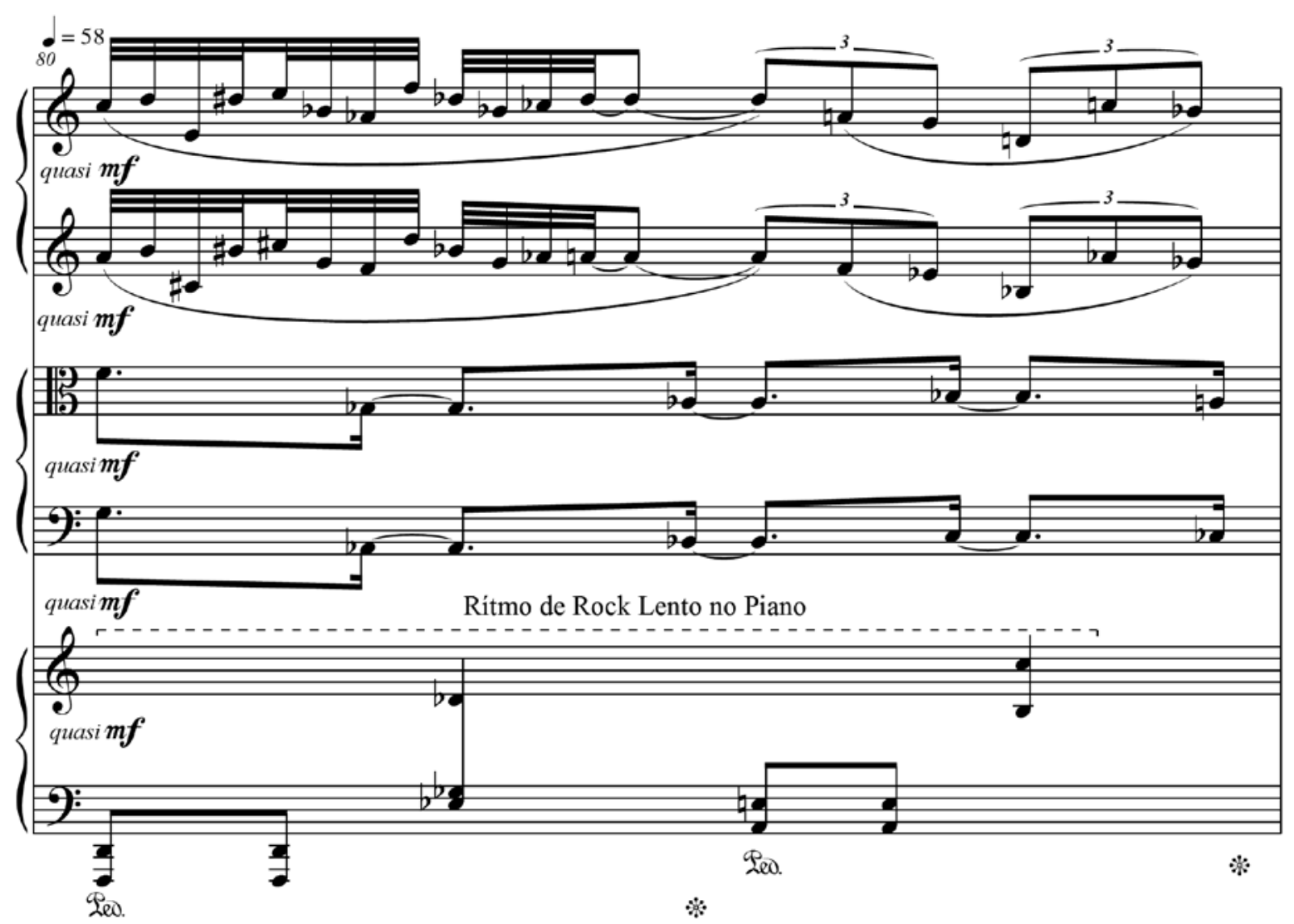

Ex.30 - Excerto do trecho atonal em Rimsky de Gilberto Mendes (c.80) 
ADORNO (1999), no fetichismo dos materiais, levando a audição ao gozo meramente metonímico. Em outras palavras, promove a reabilitação do prazer e a diminuição da crítica, escamoteando a transparência do modo de produção das obras.

Devemos considerar que um dos fatos significativos no pós-modernismo é que, através do desterro da linguagem (já iniciado no modernismo) na verdade o que ocorre (contrariamente a este) e contraditoriamente, é uma procura da significação (da comunicação perdida decorrente do vazio e da abstração deixados pelo formalismo), restando como única saída, a reabilitação dos materiais do passado. Daí porque a descontinuidade tornar-se sistemática (o que, por outro lado, incorre na cilada de incidir num outro tipo de normatividade).

Em Rimsky, constatamos a não utilização de uma sintaxe tradicional teleológica. Os materiais utilizados possibilitam a formação de presentes sincrônicos, onde as "oposições" não mais se contradizem, somente se chocam. A multiplicidade abole o ponto de vista único para afirmar a ausência de centro e de convergência. $A$ justaposição nega a dialética, afirmando o caos. Não há desenvolvimento. No entanto, o uso de repetições de notas inseridas na série, como também as repetições dos fragmentos apresentados em descontinuidade, parece uma tentativa de facilitar a assimilação que requisita a necessidade de ouvi-los de novo. Seria essa uma forma de possibilitar (contraditoriamente) a fixação e a memorização perdida na descontinuidade?

Constatamos que a arte para Mendes demanda espiritualidade e transcendência em relação aos assuntos cotidianos (MENDES, 1994, p.62-63), despojamento ascético, liberdade, ética, contemplação. Porém, podemos também afirmar que a utilização das contaminações que introduzem elementos populares acaba favorecendo a eliminação da aura da arte por privilegiar a sensação e a imersão, negando a contemplação almejada por Mendes, embora este não veja aí uma irreconciliabilidade. Ao contrário, Mendes não pretende eliminar a aura da arte, mas defendê-la.

Em Rimsky, a "Sheherazade de Mendes", cuja apropriação descaracteriza o ritmo original para sua transformação numa versão ainda mais popularizada porque impregnada do balanço da bossa-nova (MENDES, 1994, c.74), acaba por enfatizar mais o pólo popular do que o erudito, do qual mantém somente a melodia em excerto. Já o trecho atonal, como referente modernista (MENDES, 1994, c.80), superposto ao acompanhamento do piano como rock lento, contém uma densidade e complexidade que acaba enfatizando melhor, como decorrência, o aspecto abstrato do que permitindo desvelar o conteúdo referencial do ritmo do rock, cuja escuta quase não o reconhece, diluindo-o na urdidura. Dito de outra forma: no trecho atonal a opção pelo procedimento inclusivo acaba obliterando as referências populares, recaindo mais para o efeito hermético, conformando-se em contraposição à figuração como elemento portador de compreensibilidade.
Podemos sintetizar esta questão numa pergunta: qual é a eficácia do excesso, se o que prevalece é a indistinção e a textura? $\mathrm{Ou}$, contrariamente, a proposta desse hibridismo seria mitigar a tensão? 0 trecho atonal, representando os parâmetros modernistas (mesmo com a inclusão do elemento popular) não pode favorecer a aproximação do público desacostumado à apreciação desse código. Reitera apenas o procedimento (excessivo) de inclusão defendido no pós-modernismo, de reafirmar seu pretenso caráter democrático para realizar o afastamento de uma compartimentação maniqueísta.

Concluímos que as contaminações ou hibridações podem contribuir para diminuir ou amenizar as fronteiras entre o popular e o erudito, mas não conseguem sua supressão. Para os sabedores de que devemos evitar o maniqueísmo há também a necessidade de reconhecimento das contradições como impossibilidades de uma verdadeira fusão de categorias distintas. Os adeptos da atitude pós-moderna, no entanto, admitem as contradições sem questioná-las. Dentro desta lógica, no entanto, estes podem recair em um só lado da antítese, fato que tanto negam, como observa Terry EAGLETON (1998). Admitir a contradição significa supor que na medida em que não há mais restrições, não há mais conflito.

A tentativa de desfazimento das oposições entre arte culta e arte inferior instaura a questão do uso de elementos característicos da cultura de massa que viabilizem o consumo da obra. Desta forma a arte pode correr o risco de ser facilitada. Como conciliar sofisticação com o que é popular? Como dissemos, Mendes tenta solucionar essa dualidade resgatando a música popular norte-americana dos anos 30 e 40 naquilo em que esta é comparável à arte de elite, rejeitando a conjunção entre arte e mercadoria. Sua concepção de arte vincula-se aos pressupostos modernistas de autonomia, de elitismo, endereçada a seus pares, contrário à indústria cultural. Renega os pressupostos do grupo Música Nova (atrelado aos temas de atraso e progresso) e volta-se para o antigo desprezo vanguardista pela indústria cultural. Enfatizando o aspecto semântico (referências, evocações) de suas composições da $3^{\text {a }}$. fase, ele pretende não ser acessivel, nem comunicativo (MENDES,1994, p.113) mas defende ao mesmo tempo a possibilidade de compreensão de sua música pela classe operária (MENDES, 1994, p.113). Tenta escapar da polarização entre arte de elite e arte popular, derrubar as barreiras do preconceito, procurando solucionar as contradições na verdade insolúveis entre as classes sociais. Mendes procura evitar e rigidez e concebe a construção do sentido deslocada mais para o subjetivo, o passional, o intuitivo do que para o racional (MENDES,1994, p.169-170). 0 cerne do problema está em desfazer a rigidez e ao mesmo tempo não cair na vulgarização, na mediocridade corrente da arte de massa cuja finalidade é entretenimento e comunicação. É assim que para evitar a mediocridade Mendes volta-se para uma aristocracia do espírito elevando o popular para a transcendência (MENDES, 1994, p.171). Mas a fusão das esferas alta e baixa, 
como dissemos, é utópica. Se afirmarmos a inexistência de fronteiras entre o erudito e o popular alegando que só o que existe na verdade é a música (classificada como boa ou ruim), estaremos caindo em polarizações que remetem a categorias de valor que rejeitam as demais atribuições concorrentes: reincidimos num dualismo e numa posição igualmente absolutista. Bom ou ruim demonstra, portanto, a função social de suas respectivas legitimações. Não reconhecer isso é uma forma de imprimir e sobrepor os conceitos das classes dominantes para as massas. Caberia a pergunta: qual a verdade do oprimido?

Devemos lembrar que a estética popular implica na subordinação da forma à função e que a estética erudita propugna critérios de julgamento sobre o modo de produção das obras a despeito da função. 0 gosto sofisticado pressupõe a aversão ao gosto vulgar, por supor sujeitos sociais diferentes que traduzem suas posições de acordo com as distinções que os exprimem. Música popular e música erudita são separadas por conceitos sociológicos que consideram diferentes performances, convenções e instituições (a bossa-nova, por exemplo, é um fenômeno burguês). Portanto, a arte, se pensada em termos de produção necessita que reconheçamos o binômio "produção/ consumo" ligado a processos formais que se constituem em músicas de diferentes tipos e separadas sociologicamente. Mesmo com a introdução da banalidade, das referências populares, dos estilemas, essa música (possuidora dessa sintaxe onde o procedimento inclusivo admite 0 erudito) não é consumida e assimilável pelas classes populares. Como já frisamos, o hibridismo tem seus limites verificados no modo de produção, no consumo, na circulação e na recepção das obras como forma de distinção (conforme BOURDIEU (1979) e BRACKETT (2002)).

Se, por um lado Mendes faz positivamente a crítica à mediocridade (do popular?) hoje existente na nossa sociedade de massa, denunciando sua estrita dependência da lógica comercial onde ele nos confessa a dificuldade de sobrevivência a uma modernidade filisteia, por outro lado, na sua tentativa de resistência às tendências de dissolução do belo e daquilo que ele chama de verdadeira arte, evitando a perda de sua qualidade, faz um esforço para garantir a perenidade do artista na procura de uma essência que se perdeu. Porém, em nossa contemporaneidade não há mais espaço para a realização de uma arte inteiramente autônoma. 0 mercado é uma instância intrínseca à produção que vê a arte como produto legítimo da sociedade capitalista, o que faz com que a estética retorne à sua origem mundana. Neste aspecto, paradoxalmente, Mendes defende a reintrodução do belo na arte contemporânea aproximando-se de Adorno no sentido de uma estética que pode ser considerada contrária ao embrutecimento do homem e de certa forma, saudosista. Ao defender o belo, contrapõese à mudança da noção de obra de arte feita pela modernidade que já realizara sua dessacralização.

Sabemos que o belo clássico salientou a preocupação com a qualidade da obra, com a contemplação, com a transcendência, com o valor de culto, com a aura. A modernidade, através da aceleração das forças produtivas e da consequente mutação das condições de produção, afluiu na ideia de artista como trabalhador, matando a originalidade da obra para possibilitar a fruição (em contraposição à contemplação). Ao negar a produção e o consumo, Mendes posiciona-se contra a mutação da arte e do artista. A reintrodução da contemplação corresponde ao retorno da aura numa época secularizada a qual mantém como consequência, a preservação das categorias ideais. Esta constatação abala a crítica da metafísica iniciada na modernidade. Neste período a arte atacou a materialidade da obra para atacar a aura, transformando o sagrado em profano. Concernente ao pós-modernismo, verificamos por um lado, a quebra da seriedade (propiciada pelas contaminações) e do rigor que favorecem e imersão e consequentemente diminuem a distância imposta pela obra imbuída de aura. Por outro, a constatação concomitante da existência de compositores críticos do capitalismo, defensores da noção de criação, genialidade e arte contrária à instrumentalização. Perguntamos: fazse música para que o ouvinte realize a semiose que quiser, ou ainda existe a intenção do autor?

Compreendemos que em suas contradições, Mendes reflete as da sociedade em que vive. As afirmações de Mendes nos revelam as aporias em que se encontra o compositor contemporâneo na necessidade de reescrever sua vida.

Ao rejeitar a ideia de progresso o pós-modernismo elide a vanguarda, encerrando a dissidência e o "make it new". Este, como transgressão, não poderia ser infinito. Não há mais rebeldia, nem revolução, nem recusa, nem negação. 0 que pode haver é a novidade que não mais tem mais impacto, não é mais intempestiva. 0 novo não tem mais poder de transformação porque o que outrora foi contundente, torna-se repetição. 0 que está aí não muda o que já foi conquistado pela modernidade porque não contém mais o choque da estranheza, apenas a simples diferenciação. À medida que não há mais proibições, a utilização da profusão de materiais torna-se equalizada, não havendo mais necessidade de ruptura. Do lado da recepção da obra o que constatamos é uma indiferenciação que não remete mais à perplexidade. De onde se conclui que os ready mades de hoje não mais produzem impacto. Concluímos que o procedimento de reabilitação dos materiais do passado e a preocupação da transcendência podem levar ao distanciamento da realidade objetiva. A utilização da prática das citações deve, portanto ser amplamente considerada. A citação, ao tornar-se maneira de fazer, moda, pode tornar-se um perigo, como no consumo de mercadorias, onde o retro não causa nenhum impacto, mas acatamento, estabilidade, perda de contundência. 0 procedimento inclusivo de materiais do passado pode apenas reintroduzir o antigo de forma fetichizada, lúdica e ornamental. Faz-se mister, portanto, refletir sobre como não negar o consumo e ao mesmo tempo não ser consumido pelas imposições do capital. Como dissemos, as concepções estético-ideológicas pósmodernas estão atreladas ao moderno sem superá-lo. 0 
pós-modernismo não é uma ruptura, uma vez que não há mais normas a quebrar. Nega a história, não tem compromisso com a verdade, não comporta mais nenhuma tensão entre presente e passado. A intenção pós-moderna é abater a austeridade, o hermetismo, o que assegura maior facilidade de assimilação (requisitos encontrados nas tendências da Nova Consonância e da Nova Simplicidade). Em outras palavras, o pós-modernismo para evitar ser prescritivo pretende, neste sentido, não propor nada. Recusa a negatividade, sendo essa sua política apolítica. Vimos que "pós-moderno" não é um termo que possa caracterizar nossa contemporaneidade como critério claramente definido. Peter BURGER (1988) reconhece no pós-moderno a atenuação de uma rígida dicotomia entre arte superior e arte inferior onde não existem materiais avançados, uma vez que todos os repertórios históricos de materiais estão igualmente disponíveis ao artista. Ele alerta, no entanto, para que o fascínio dos materiais não seja transformado em critério de apreciação estética, devendo se desfazer de um manuseio arbitrário para realizar uma reflexão sobre a autonomia da arte e das condutas artísticas. Neste sentido, quanto à constatação de uma crise da arte ele adverte que, tanto a exigência de abolição da separação entre e vida quanto a aceitação destas, poderão incorrer no fim da arte.

\section{Referências}

ADORNO, Theodor W. - "O fetichismo na música e a regressão da audição". In: Coleção Os pensadores -Textos Escolhidos. São Paulo: Nova Cultural, 1999, p.65-198.

BENJAMIN, Walter - "A obra de arte na era da reprodutibilidade técnica". In: Obras Escolhidas - Magia, Técnica, Arte e Política. São Paulo: Editora Brasiliense,1996, v. 1.

BOURDIEU, Pierre - La distinction - critique sociale du jugement. Paris: Les Éditions de Minuit, 1979.

BRACKET, David - "Where's It Art": Postmodern Theory and the Contemporary Musical Field. In: LOCHHEAD, Judy and AUNER, Joseph - Postmodern Music/Postmodern Thought. New York: Routledge, 2002, p.207-231.

COELHO DE SOUZA, Rodolfo - Encarte do CD Gilberto Mendes - piano solo - Rimsky.

BURGER, Peter - "O declínio da Era Moderna". In: Novos Estudos CEBRAP no. 20, março de 1988, p.81-95

CALABRESE, Omar - A Idade Neobarroca. Lisboa: Edições 70, 1988.

DELEUZE, Gilles e GUATTARI, Félix - 0 que é a Filosofia? São Paulo: Editora 34, 2004.

- Mil Platôs - Capitalismo e Esquizofrenia. São Paulo: Editora 34, 2004, vol. 1, 3 e 4.

EAGLETON, Terry - As ilusões do pós-modernismo. RJ: Jorge Zahar Ed., 1998.

HUTCHEON, Linda - Poética do Pós-Modernismo - História. Teoria. Ficção. Rio de Janeiro: Imago, 1991.

MENDES, Gilberto - Uma odisséia musical - dos mares do sul à elegância pop/art déco. São Paulo: EDUSP, 1994.

TEIXEIRA COELHO - Moderno pós Moderno - modos e versões. São Paulo: Iluminuras,2001.

\section{Partituras:}

MENDES, Gilberto - Rimsky, 27 p.(partitura com escrita de próprio punho do autor).

RIMSKY-KORSAKOV, Nikolai - Sheherazade - Suite Sinfonica op.35 (redução para piano) de Teodor Fuchs. Buenos Aires: Ricordi Americana, $59 \mathrm{p}$.

- Quinteto em Si bemol Maior (op.post.) - para piano, flauta, clarineta, trompa, fagote. New York: International Music Company, $64 \mathrm{p}$.

\section{Documento eletrônico:}

www.remue.net/cont/Blanchot_Hoppenot.pd Acesso em: 21/06/2006.

\section{Reprodução sonora (CD):}

Gilberto Mendes - Piano solo - Rimsky (edição do Programa Petrobrás de Música 2002, realizado pelo Laboratório de Acústica Musical e Informática da ECA/USP, Março-Setembro de 2003). Quarteto de cordas da Cidade de São Paulo: Betina Stegman ( $1^{\circ}$.violino), Nelson Rios ( $2^{\circ}$.violino), Marcelo Jaffé (viola), Robert Suetholz (violoncelo), Lídia Bazarian (piano). 


\section{Notas:}

1 Escritor e crítico literário espanhol (1885-1966).

2 BUCKINX, Boudewijn - O Pequeno Pomo - ou a história do pós-modernismo. São Paulo: Ateliê Editorial, 1998.

3 Referência verificada na apresentação do encarte (assinada por este autor) do CD "Gilberto Mendes - piano solo - Rimsky."

4 Empregamos a concepção de rizoma postulada por Deleuze por acreditarmos que esta traduz melhor a ideia de uma linha (justaposta, segmentada), cujo "motor" é o desejo (CALABRESE,1988) que nega o principio da unidade em defesa da multiplicidade de materiais. Deleuze prescreveu: "Faça o rizoma e não a raiz, nunca plante! Não semeie, pique! Não seja nem uno, nem múltiplo, seja multiplicidades! Faça a linha e não o ponto (...)." (Cf. DELEUZE; GUATTARI, 2007, p.36). Nosso interesse é o de demonstrar que essa acepção de rizoma personaliza o imperativo de uma heterogeneidade instaurada numa grande linha contínua que por sua lógica nômade simultaneamente a contém e a oblitera.

5 Estilemas: constantes estilisticas, traços de estilo, de códigos em desuso (TEIXEIRA COELHO, 2001, p.67).

6 Obs.: A citação do Quinteto para piano e sopros de Rimsky Korsakov, o "minimalismo", "rock lento" e "música para cinema" foram existentes indicados pelo próprio compositor. A presença de "fox trot" também por ele afirmada, porém sem sua devida localização, nos levou a detectá-la, por inferência, nos compassos 90-94 devido à similitude de seu componente rítmico.

7 Apesar de o autor incorporar uma recapitulação dos elementos apresentados.

8 Refiro-me à inaplicabilidade do critério de autenticidade da produção artística que deixa de ter valor de culto como objeto único (a questão da originalidade anteriormente comentada) e se torna dessacralizado, explicitado por Walter BENJAMIN (1996).

9 Idioma: usado aqui no sentido de conter uma gramática (escalas, padrões, estruturas ritmicas e intervalos). Possui uma dupla função: simultaneamente alude e desfaz o reconhecimento.

10 Como no pensar de Deleuze, agora a riqueza em termos sintáticos não trata mais de impor uma forma à matéria, mas de manter juntos os heterogêneos, sem deixar de ser heterogêneos (DELEUZE; GUATTARI, 1980, p. 141).

11 Aqui é necessário reportarmo-nos às observações de Linda Hutcheon sobre a duplicidade paradoxal do pós-moderno. Este está atrelado ao modernismo não rejeitando-o por completo mas, inserindo e subvertendo seus códigos: evidenciamos na paródia simultaneamente deferência e transgressão (HUTCHEON,1991).

12 Esse é um requisito também necessário quanto à citação apropriada por requerer do ouvinte a erudição das obras em seus contextos para poder avaliar a transgressão efetuada, pois do contrário esta não pode ser percebida.

13 Podemos fazer outra leitura da utilização da série feita por Mendes. Esta pode também significar uma alusão à rigidez (como medida irônica, uma vez que a série de Mendes não a contém e cujo detalhe só se percebe através de sua análise) do modernismo (no caso a série como elemento de ordem) ao prenunciar os demais elementos (livres, heterogêneos e casuais) que lhe seguem. Este procedimento pode ser visto como uma medida conciliatória onde a oposição de precisão e imprecisão nos sugeriria a associação de dois gostos como a única maneira possível de tentar "organizar" a sintaxe. Também a existência de uma recapitulação verificada depois da cadenza no piano (a partir do compasso 102 até o fim da peça promovendo o retorno do tango, do ritmo nas cordas, da bossa nova, da melodia derivada da série acompanhada pelo rock lento no piano) sugere a intenção de recuperar uma retórica cujos princípios formais embora já estejam perdidos são reintroduzidos por Mendes. Devemos considerar que a destruição da forma e dos nexos se traduz na descontinuidade, impedindo a capacidade de recordar pra frente, sendo a recapitulação a única maneira de favorecer a rememoração do ouvinte (em contraposição ao modernismo) através da repetição dos elementos anteriormente apresentados.

14 Quanto mais a representação se desvincula de seu referente, mais o som representa a si mesmo, isto é, mais ele é concreto. Neste sentido, a possibilidade de abstração em música faz-se através do corte dos vínculos com as figuras tradicionais de reconhecimento.

15 Devemos lembrar que já no séc. XV, num outro contexto e com diferentes motivações, a melodia pagã "chanson de I'homme armé" foi amplamente utilizada pelos compositores como cantus firmus e pretexto para o emprego da forma canônica na produção da polifonia (como referência pagã nas missas religiosas, porém de difícil identificação para os leigos em sua urdidura). Contudo, vemos nesse processo o intuito de exprimir o que era conhecido como a ciência musical da época.

16 Devemos frisar que neste sentido encontramos exceções no pós-modernismo como no caso de Schnittke, compositor que melhor expressou sua resistência intelectual e simbólica ao Comunismo através de sua atração pelo irracional e pelo seu extremo pessimismo. Desta forma, Schnittke destoa do hedonismo pós-moderno ao optar pela expressão dramática.

170 ecletismo inclui a citação, a mistura estilistica, e o pastiche como formas que através de sua coexistência se tornam indiferenciados.

18 De acordo com HOPPENOT (cf. documento eletrônico na bibliografia) a fragmentação pós-moderna produz a desorganização do estado perceptivo temporal que paradoxalmente não se opõe à continuidade causando, ao mesmo tempo, sua destruição. Ele afirma: "cada fragmento é uma totalidade que nega a totalidade" (...) "onde a ausência de tempo leva à superabundância de tempo".

19 Não nos esqueçamos, no entanto, que aquilo que Mendes considera como a boa música orquestral norte-americana desses anos foi um produto historicamente situado, não afastado do cotidiano e que também respondia às manifestações de uma cultura de mercado.

20 David BRACKETT (2002) defende essa ideia ao constatar as diferenças de procedimentos existentes nessas esferas.

21 Observamos que John Zorn (1953), compositor norte-americano e saxofonista, que se utiliza de um verdadeiro caleidoscópio de materiais como que acionados por controle remoto faz música que não pode ser considerada popular, sendo consumida no máximo por jovens intelectuais. Suas composições receberam as etiquetas de vanguarda, jazz, experimental, free jazz, ruído.

22 "make it new" - termo proposto por Ezra Pound: significa "tornar algo novo", achar alguma ideia nova no sentido de não ter sido ainda pensada.

Vera Lúcia Rocha Pedron Peres é graduada em História pela FFLCH (USP) e mestre em Artes (programa de Música em Processos de Criação Musical pela ECA - USP) sob a orientação do Prof. Dr. Rogério Luiz Moraes Costa. Estudou harmonia e estética com o Prof. Hans-Joachim Koellreutter e piano com os professores: Sebastina Benda, Caio Pagano, Amílcar Zani e Nahim Marun. 